\title{
Why the Google Books Settlement is Procompetitive
}

\section{Citation}

Einer R. Elhauge, Why the Google Books Settlement is Procompetitive, $2 \mathrm{~J}$. Legal Analysis 1 (2010).

\section{Published Version}

http://dx.doi.org/10.1093/jla/2.1.1;http://jla.oxfordjournals.org/content/2/1/1.full.pdf

\section{Permanent link}

http://nrs.harvard.edu/urn-3:HUL.InstRepos:11222684

\section{Terms of Use}

This article was downloaded from Harvard University's DASH repository, and is made available under the terms and conditions applicable to Open Access Policy Articles, as set forth at http:// nrs.harvard.edu/urn-3:HUL.InstRepos:dash.current.terms-of-use\#OAP

\section{Share Your Story}

The Harvard community has made this article openly available.

Please share how this access benefits you. Submit a story.

Accessibility 


\title{
WHY THE GOOGLE BOOKS SETTLEMENT IS PROCOMPETITIVE
}

\author{
Einer Elhauge ${ }^{7}$
}

\begin{abstract}
Although the Google Books Settlement has been criticized as anticompetitive, I conclude that this critique is mistaken. For out-of-copyright books, the settlement procompetitively expands output by clarifying which books are in the public domain and making them digitally available for free. For claimed in-copyright books, the settlement procompetitively expands output by clarifying who holds their rights, making them digitally searchable, allowing individual digital display and sales at competitive prices each rightsholder can set, and creating a new subscription product that provides digital access to a near-universal library at free or competitive rates. For unclaimed in-copyright books, the settlement procompetitively expands output by helping to identify rightsholders and making their books saleable at competitive rates when they cannot be found. The settlement does not raise rival barriers to offering any of these books, but to the contrary lowers them. The output expansion is particularly dramatic for commercially unavailable books, which by definition would otherwise have no new output.
\end{abstract}

JEL Codes: K21, L12, L40, L41, L42, L49.

Keywords: Google, Books, Google Books, Google Books Settlement, Copyright, Digital Books, cartel, monopoly, monopolization, orphan books, out-ofcopyright, out-of-print, entry barriers, restraints of trade, Internet, antitrust.

\section{INTRODUCTION AND SUMMARY}

The Google Books settlement gives Google default rights to digitize and make searchable all books published before January 5, 2009, and to display and sell digital versions of all commercially unavailable books, unless the book rightsholder chooses otherwise. This settlement has been criticized by those who argue that it creates an effective cartel among rightsholders

1 Petrie Professor of Law, Harvard Law. I am grateful for extraordinarily able assistance from Mitchell Reich, for comments from the anonymous peer reviewer, and for research support from Google, Inc. The conclusions here are mine, not theirs, and should also not be taken to reflect the views of Harvard University. 
and a de facto monopoly over digital sales of commercially unavailable books. However, I conclude these antitrust critiques are mistaken. The settlement procompetitively increases book output by expanding unfettered competition in book licensing and reducing legal and logistical barriers to their distribution by both Google and its rivals. In short, it has no anticompetitive effects and dramatic procompetitive effects, including resurrecting a treasure trove of intellectual heritage that would otherwise largely be lost and making books more easily accessible to more persons than they ever have been in history. My analysis throughout will be of the Amended Settlement Agreement that is currently pending. Because the analysis is complex, I begin by summarizing my conclusions for each category of books.

Out-of-Copyright Books. Because the settlement only governs in-copyright books, one might mistakenly think it does not affect out-of-print books. But it does. Currently, uncertainty about whether a book is out of copyright deters firms from offering many books that are actually out of copyright. The settlement has provisions that create and fund a process to clarify which books are actually out of copyright, thus expanding the number of books that are effectively in the public domain and allowing Google to add them to the books that are fully searchable and available for free downloading online. This procompetitively expands output by taking a set of books that previously were impossible or costly to find or own and making them easy and free to find and own. The settlement imposes no barrier for Google rivals who wish to distribute these books. To the contrary, it affirmatively lowers those barriers because the settlement allows rivals to free ride on Google's costs of digitizing those books and clarifies which books are in the public domain. The expanded availability of free out-of-copyright books should also put downward pressure on usedbook prices for these books and to some extent on licenses and prices for in-copyright books.

Commercially Available Books. The settlement procompetitively provides a process for making decisions in the face of uncertainty about who owns digital rights to commercially available books, thus easing the digital licensing of these books and increasing the output of digital commercially available books. The settlement also expands the sales of commercially available books by making them searchable on Google and directing searchers to the firms that sell them, thus helping buyers locate the books they want to buy, whether in printed or digital form. Finally, the settlement provides 
an additional nonexclusive vehicle for promoting commercially available books, allowing rightsholders to choose to have Google display and sell their books at a price each individual rightsholder can individually set, which economic analysis indicates would create enormous benefits to consumer welfare. The settlement imposes no barrier to digital distribution of these books by Google rivals, which can distribute these same books if the rightsholders want at any price they wish, and indeed lowers barriers to Google rivals by providing information on how much digital demand there is for each book.

In-Copyright Books That Are Commercially Unavailable. The settlement also procompetitively expands sales of books that are in copyright but commercially unavailable. The settlement defines a "commercially available" book as any in-copyright book (digital or not, as long as any digital copy was not obtained from Google's scanning project) that some seller offers for sale new, at the future time in question. ${ }^{2}$ Thus, a commercially unavailable book is by definition a book for which there would be zero new output unless the settlement allows Google to offer its scanned books for sale. The settlement makes all these commercially unavailable in-copyright books by default searchable and available for preview and sale on Google. This creates additional output that otherwise would be nonexistent and vastly increases the availability of these books, which otherwise would be limited to those who can find them for resale on the used-book market or for loan from a library. The settlement also increases the number of these books whose rightsholders would be known by clarifying whether authors or publishers own their rights, creating a Book Rights Registry funded to locate rightsholders, and paying royalties to registered rightsholders that incentivize unknown rightsholders to come forward. This increase in known rightsholders will increase licensing competition and further increase the output of digital books, whether through Google or its rivals.

Competition among books that are claimed by rightsholders is entirely unrestrained, because any rightsholder can set its own book price for sale

2 Amended Settlement Agreement \$1.31, Authors Guild, Inc. v. Google Inc., S.D.N.Y. Case No. 05 CV 8136-DC (Nov. 13, 2009) [hereinafter "Amended Settlement"] (“Commercially Available' means ... that the Rightsholder ... is, at the time in question, offering the Book (other than as derived from a Library Scan) for sale new, from sellers anywhere in the world, through one or more then-customary channels of trade into purchasers within the United States, Canada, the United Kingdom or Australia."); $\$ 1.19$ (defining “Book" to exclude "work in, or as they become in, the public domain"); $\$ 1.81$ (defining a "Library Scan" as a digitized copy obtained through the Google's scanning project). 
through Google and remains free to sell its books through any Google rival. For a commercially unavailable book that has a rightsholder who elects not to set a price or who is unknown, the settlement requires Google to set a price using an algorithm designed to mimic competitive pricing. Google has ample incentives to follow this algorithm faithfully because low book prices would increase its web traffic and revenue from advertising (which provides 97 percent of Google's revenue), and in any event any effort to set a supracompetitive price would be constrained because known rightsholders would have incentives to undercut it. Although unknown rightsholders by definition cannot set prices for their unclaimed books, ${ }^{3}$ prices for unclaimed books would also be constrained by the settlement algorithm, by Google's incentives not to sacrifice advertising revenue, by competition from claimed books, and by the fact that any supracompetitive price would incentivize unknown rightsholders to identify themselves. In any event, unclaimed books would by definition be unlicensable absent the settlement, making the but-for price for new output of unclaimed books effectively infinity, so that the settlement can only lower their price and expand their output. Further, by lowering the number of unclaimed books, the settlement lowers the number of books with this effectively infinite but-for price on new output.

Nothing in the settlement impairs the ability of Google rivals to offer in-copyright books that are commercially unavailable. There are barriers to offering such books, but they are created by the costs of digitizing these books, the transaction costs of locating and negotiating with rightsholders, and the risk-bearing costs of situations where rights or their value are unclear or unknown. The settlement overcomes these barriers to entry for Google without raising them for any rival because every right the settlement gives Google is expressly nonexclusive. Far from increasing rival entry barriers, the settlement affirmatively lowers rival transaction and risk-bearing costs in a number of ways. First, the settlement helps rivals value digital books by revealing the extent of buyer demand for them, thus helping rivals decide which books to license for digital use. Second, the settlement creates

3 I will use the term "unclaimed books" rather than "orphan books" to refer to books with unknown rightsholders because the term "orphan books" is misleading. Orphans have no parents, whereas so-called orphan books have rightsholders whose identity or location is unknown. (If they had no rightsholder, they would be out of copyright and thus pose no issue.) Because a key benefit of the settlement is converting unknown rightsholders into known rightsholders, it is clearer to refer to these books as "unclaimed books." 
a public database of rightsholders in claimed books that lowers rival costs in identifying and contacting them. Third, the settlement funds a search for rightsholders of unclaimed books, allowing rivals to avoid the transaction costs of finding them or the risks of offering unclaimed books without a license.

Indeed, the settlement may lower rival entry barriers even further because it allows licensing to Google rivals of claimed books by the Registry and of unclaimed books by the Unclaimed Works Fiduciary "to the extent permitted by law." 4 This raises two possibilities, depending on what one thinks the law permits a class action settlement to cover. If a class action settlement can legally authorize the Registry and Fiduciary to grant Google rivals the same default licenses over commercially unavailable books that Google gets under the settlement, then the settlement grants that authority. The Registry and Fiduciary have every incentive to exercise whatever licensing authority they have to get better distribution or a lower distribution markup. Such a settlement-created licensing authority would thus dramatically lower rival barriers to entry and create full competition in digital distribution of commercially unavailable books. If the settlement cannot legally give the Registry and Fiduciary authority over default licensing, then the settlement grants authority to license Google rivals only to the extent that the Registry gets post-settlement authority from the rightsholders to do so. This still lowers rival barriers to entry because the Registry has incentives to collect licenses and relicense them in aggregate form to improve distribution or lower markups. Whatever one's conclusion of what is "permitted by law," the settlement by definition did all it legally could to allow licensing of Google rivals.

In contrast, barring the settlement would anticompetitively raise entry barriers to prohibitive levels for Google and any other firm hoping to distribute books that are in copyright but commercially unavailable. Absent a class action settlement, the transaction and risk-bearing costs created by copyright law would be too high to distribute these books, resulting in zero output. A holding that such a settlement violates antitrust law would not only prevent Google from overcoming these entry barriers, but set a precedent preventing any rival from overcoming them either, condemning us all to zero output of these books and an effective price of infinity for new copies of them. 
Institutional Subscriptions to All Google Books. The settlement also creates a brand new product, the institutional subscription, which gives institutions the ability to fully view all commercially unavailable books that are available for purchase under the settlement and all commercially available books whose rightsholders elect to include them in the subscription. This sort of blanket license is totally unfeasible today, and adding a market option that otherwise would not exist can only be procompetitive. Google must provide this institutional subscription for free at one or more terminals per college or public library. For other institutions, the settlement requires that subscription fees be set to earn only competitive market rates and to ensure the sort of broad access that would exist with competitive market output. Further, any ability to set supracompetitive prices for institutional subscriptions would be constrained by competition with other book sources (which the settlement enhances) and by Google's incentives to keep the price low to increase the advertising revenue that provides 97 percent of its current revenue. Nor does the settlement in any way increase the barriers that Google rivals might face in offering similar institutional subscriptions. To the contrary, it lowers those barriers for the same reasons described above for all books, whether commercially available or unavailable.

Other Procompetitive Benefits. The Settlement also provides a sundry of other powerful procompetitive benefits. It makes all displayed books available to the 15-30 million print-disabled Americans, who currently can access only a small subset of these books. It creates a digitized database of almost all books, which researchers can use to conduct research in linguistics, translation, or search protocols that currently would be impossible. It encourages a digitization of books that protects against books getting damaged or lost to history. Finally, it dramatically aids general research by making the bulk of past published books available online for free search, free preview, and free or lower cost purchase, thus curing the unfortunate tendency of current research to unduly favor less-developed, more-recent works because of their greater online availability.

Precedent. The settlement compares favorably to the blanket licenses for copyrighted songs that the opinions in BMI v. CBS held were too procompetitive to be subject to the per se rule and too lacking in anticompetitive effect to violate the rule of reason. There, as here, transaction costs made direct licensing with many rightsholders costly, and the agreements created an intermediary that offered a blanket license covering all their works but left individual rightsholders free to license directly. The Supreme Court 
concluded that lowering transaction costs and creating the new product of a blanket license were procompetitive justifications that made the per se rule inapplicable, and the lower appellate court concluded that the ability to directly license with individual rightsholders eliminated any anticompetitive effect. The same logic is equally applicable here, with the difference that the settlement is even less restraining in multiple respects. First, the $B M I$ intermediary offered blanket licenses but not individual songs, and the plaintiff sought the remedy of requiring individual song sales. In contrast, the settlement requires Google to offer books on both a blanket and individual basis, and thus already provides the very market option of single sales that the $B M I$ plaintiff sought as a remedy. Second, the BMI rightsholders could not set their own prices for sales through the intermediary, whereas the settlement allows rightsholders to set their own prices for sales through Google. Third, the BMI rightsholders could not license the same song through a rival intermediary, whereas the settlement allows rightsholders to license their books for distribution through any Google rival and Google at the same time. Thus, given that the BMI agreement was neither per se illegal nor a rule of reason violation, the Google books settlement cannot violate antitrust law either.

\section{ENTRY BARRIERS AND THE BUT-FOR BASELINE}

Understanding the effects of the Google books settlement requires first understanding what the but-for world would look like without the challenged settlement provisions. Nothing in the settlement in any way diminishes the ability of any Google rival to compete in distributing digital books. True, there are obstacles to doing so, but they are not obstacles imposed by the settlement. Instead, they are obstacles imposed by digitization costs and the transaction and risk-bearing costs of ascertaining which books are in copyright, determining who holds any rights, locating rightsholders, and negotiating an agreement. Because every right that the settlement gives Google to digitize, display, or sell books is expressly non-exclusive, ${ }^{5}$ the

5 Amended Settlement $\$ 2.4$ ("The authorizations granted to Google in this Amended Settlement Agreement are non-exclusive only, and nothing in this Amended Settlement Agreement shall be construed as limiting any Rightsholder's right to authorize, through the Registry or otherwise, any Person, including direct competitors of Google, to use his, her or its Books or Inserts in any way, including ways identical to those provided for under this Amended Settlement Agreement.”); see also \$3.1(a) (Google’s digitization rights are “non-exclusive”). 
settlement in no way increases the barriers to entry imposed by these costs. To the contrary, the settlement reduces barriers to entry for any Google rival in several ways detailed below. Critics argue that the settlement does not lower entry barriers enough for rivals to provide the commercially unavailable books that Google will be able to provide. This claim is, we shall see, factually debatable. Moreover, if true, this claim would mean that rivals would be even less likely to offer these books in the but-for world where the settlement didn't lower those entry barriers somewhat. Disapproval of this settlement would thus, if critics are right, result in a but-for world where no one offers these commercially unavailable books, which is certainly worse than a world where Google alone offers them, especially given that the settlement commits to competitive pricing.

\subsection{How the Settlement Lowers Entry Barriers}

Lower Digitization Cost Barriers. Google has incurred the enormous cost of digitizing the books, which included labor costs, significant legal risk, and creating new technologies to automate scanning and deal with book page curvature (Harrington 2009; Clements 2009). The settlement allows Google to provide each fully participating library with a digital copy of its books. ${ }^{6}$ Those libraries are in turn free to sell those digital books to any Google rival if they are out of copyright. In fact, the University of Michigan has already used its digitized books to enter into an agreement to sell printon-demand access to hundreds of thousands of its out-of-copyright books through Amazon.com (Gershman 2009). Thus, Google rivals can free ride on Google's digitization without incurring those digitization costs when selling any out-of-copyright books. Facing this prospect, Google itself has proven willing to provide its digitized collection of public domain books to rival distributors: Sony and Barnes \& Noble have entered into agreements with Google to each market more than 500,000 out-of-copyright books that Google digitized (Stone 2009; Rich 2009). As time goes on, more and

6 Google can give "fully participating libraries" digital copies of all its books that Google digitized and even its books that Google digitized from other sources as long as a substantial portion of the library books were digitized. See Amended Settlement \$7.2(a). What makes a library "fully participating" is that it has not only agreed to have its books digitized but also agreed to conditions limiting the use of those digitized copies. Amended Settlement $\$ \$ 1.62$, 7.1, 7.2. "Cooperating libraries," in contrast, have allowed digitization of their books but have not agreed to the same conditions limiting use of those digitized copies, and thus do not receive those digital copies. Amended Settlement $\$ 1.39$. 
more of the books that Google digitized will go out of copyright and thus become available to rivals without incurring digitization costs.

Further, the settlement makes the entire corpus of digitized books available for nonconsumptive research. ${ }^{7}$ The settlement limits this availability to "qualified users," which is defined to include universities, nonprofits, government agencies, and others who agree to abide by limits on consumptive or commercial usage. ${ }^{8}$ Although the settlement thus does limit the sorts of research or commercial usage that can be made of the digitized corpus that Google paid to create, the "non-consumptive research" that the settlement permits is defined to include developing improved search algorithms, and the settlement expressly provides that "Commercial exploitation of algorithms developed when performing Non-Consumptive Research on the Research Corpus is permitted." 9 Thus, the settlement allows others to free ride on Google's creation of this research corpus by using it to discover superior search algorithms for use by rival commercial search engines.

Lower Costs to Valuing Digital Books. The settlement also lowers the barriers to rivals offering digital versions of any books by providing useful information about the extent of commercial value each book might have in digital form. Google rivals can easily free ride on this information by seeing the display price and asking rightsholders about their sales volume. They can then use this information to offer books only when their commercial value makes doing so profitable given any digitization, transaction, royalty, and distribution costs.

Lower Costs to Identifying Out-of-Copyright Books. The settlement agreement lowers the barriers for rivals offering out-of-copyright books by clarifying which books are in the public domain. Currently, books published in the United States between 1923 and 1963 are in copyright only if the copyright was both noticed in the publication and properly renewed (Hirtle 2010). It is costly to resolve when these tests are met, especially because the renewal records were not digitized and because the average value of these books can be slight compared to these costs and the risk of tens of thousands of dollars of statutory damages for mistakenly replicating a

7 Amended Settlement $\$ 7.2(\mathrm{~d})$.

8 Amended Settlement $\$ \$ 1.123,7.2(\mathrm{~d})(\mathrm{iii}),(\mathrm{vi})$.

9 Amended Settlement $\$ \$ 1.93(\mathrm{e}), 7.2(\mathrm{~d})(\mathrm{x})$. 
copyrighted book..$^{10}$ Thus, many books in this time frame have not been offered by Google or others, even though 93 percent are actually out of copyright (Ringer 1961, 220). ${ }^{11}$ The settlement lowers these costs and risks by providing a process for determining which books are out of copyright that is binding on rightsholders and funded by Google and the Registry. ${ }^{12}$ Because the settlement makes this information publicly available, rivals can free ride on it to offer all out-of-copyright books without incurring similar costs and risks. ${ }^{13}$

Lower Costs to Offering In-Copyright Books That Are Commercially Unavailable. The settlement also lowers the barriers to rival efforts to offer in-copyright books that are commercially unavailable First, the settlement lowers rival costs of identifying who holds the rights to commercially unavailable books that are in copyright. It does so in two ways: (1) The settlement provides and funds a mechanism for resolving reversion issues. ${ }^{14}$ Today, when a publisher allows a book to go out of print, it is often unclear whether the rights have reverted to the author. Resolving this issue thus lowers the costs of identifying who holds the rights even when the possible rightsholders are known. (2) Even when the reversion issue is clear, it takes effort to identify the author or publisher or their successors in interest. ${ }^{15}$ Many are unknown, which is the problem of unclaimed (orphan) books. The settlement incentivizes unknown rightsholders to identify themselves by giving them royalties if they register. The settlement also funds a Registry

10 Under the Copyright Act, rightholders can choose between (1) actual damages plus the infringer's profits or (2) statutory damages per infringed book of up to $\$ 150,000$ if the infringement was willful or $\$ 30,000$ if it was not. 17 U.S.C. $\$ 504(c)(1)$.

11 Ringer found that fewer than 7 percent of registered book copyrights were renewed.

12 Amended Settlement $\$ 3.2(\mathrm{~d})(\mathrm{v})$ \& Attachment E.

13 A book's display status on Google presumptively indicates its status because out-of-copyright books are 100 percent displayed for free, whereas no more than 20 percent of in-copyright books will be freely displayed unless a registered rightsholder specifies otherwise. See Amended Settlement $\$ 4.3(\mathrm{~b})(\mathrm{i})(1)$. Further, the settlement provides that the Registry will make publicly available which books have registered rightsholders. See id. $\$ 6.6(\mathrm{~d})$. Thus, a rival can easily identify all the books that are out of copyright by taking the set of books that are 100 percent displayed by Google and subtracting any of these books that the Registry database indicates have registered rightsholders.

14 Amended Settlement Attachment A, Article IV.

15 U.S. Copyright Office 2006, 22-34 (rightsholders can be difficult to identify because the book fails to identify the initial rightsholder, ownership has been transferred or the rightsholder has relocated, existing databases of copyright information are incomplete, and researching copyright information is difficult, costly, and uncertain to succeed). 
that is required to search for any unknown rightsholders who neglect to come forward. ${ }^{16}$ By thus identifying unknown rightsholders, the settlement will convert many unclaimed books into claimed books.

Rivals will be able to free ride on these costly efforts to resolve and locate rightsholders for commercially unavailable books because the settlement provides that the Registry will make publicly available a database that identifies all registered rightsholders. ${ }^{17}$ Because the settlement will reduce the number of unclaimed books from current levels, it will lower the transaction costs for licensing this set of books from effectively infinity to a potentially more feasible amount.

Second, the settlement will lower the risk-bearing costs of selling unclaimed books without a license. If these rightsholders have not come forward to register despite the settlement rewards for doing so, then that indicates they lack the knowledge, ability, or interest to claim their rights, thus lowering the risk that offering their books without a license would trigger a lawsuit.

Third, the settlement lowers the costs for rivals to obtain rights for a broad range of commercially unavailable books similar to those obtained by Google. The settlement does so in four ways.

(1) Lowering Costs of Mass Offers by Google Rivals to Registered Rightsholders. The settlement's creation of a public database of all registered rightsholders makes it much easier for rivals to make a mass offer directly to those rightsholders. If the rival offer is more attractive than Google's settlement terms, the rival should have no trouble getting many rightsholders to accept because the rightsholders can do so without giving up any rights to distribute via Google. True, this cannot help with unclaimed books. But because of the settlement, there will be far fewer unclaimed books, especially unclaimed books that have any significant value, because the settlement incentivizes unknown rightsholders to come forward and funds a Registry search for any that don't.

(2) Authorizing Registry to Aggregate Rights and LicenseTthem to Google's Rivals. The settlement provides that: "The Registry will be organized on a

16 Amended Settlement $\$ 6.1$ (c) (Registry “will use commercially reasonable efforts to locate Righstholders of Books and Inserts”). Google will pay \$34.5 million to initially fund the Registry. $\$ \$ 5.2,6.4$. If rightsholders do not register, after five years up to 25 percent of their unclaimed royalties can be used to search for search for unclaimed rightsholders, and after ten years, their unclaimed royalties go to charities that advance literacy, education or freedom of expression and that benefit rightsholders and the reading public. $\$ 6.3(\mathrm{a})$ (i).

17 Amended Settlement $\$ 6.6(\mathrm{~d})$. 
basis that allows the Registry ... to ..., ... to the extent permitted by law, license Rightsholders' U.S. copyrights to third parties." 18 At a minimum, this provision clearly allows the Registry to license books to Google rivals if the Registry gets subsequent rightsholder permission. Some critics argue that neither the Registry nor rightsholders would have incentives to license a Google rival (Picker 2009c, 408). But that is incorrect because they would have the same incentives to minimize the distribution markup that any upstream supplier has. ${ }^{19}$ Thus, if a Google rival would undercut the distribution markup that Google charges or be a more efficient distributor in any other way, then both the Registry and individual rightsholders would have incentives to license that rival. Accordingly, the Registry would have incentives to ask each registrant to authorize it to license rivals, each registrant would have incentives to give that authority, and the Registry could then license all authorized books in aggregate to any rival.

(3) Possibly Authorizing the Registry and Fiduciary to License Default Rights to Claimed and Unclaimed Books. The settlement arguably provides an even lower cost way for rivals to obtain default rights to offer commercially unavailable books because the settlement allows the Registry to license claimed books, and the Fiduciary to license unclaimed books, "to the extent permitted by law." 20 The effect of this provision depends on what one believes the law permits. Suppose one believes that the current class action settlement could not itself legally permit the Registry or Fiduciary to license Google's rivals because there is no current case or controversy involving those rivals. Then this provision means only that the settlement does not preclude the Registry and Fiduciary from licensing books to Google's rivals, but the provision does not itself affirmatively confer authority to grant such licenses. Such permission would instead have to be obtained either from the rightsholders directly, from settlement of a second class action by the rightsholders against Google's rivals, or from new legislation covering unclaimed books. In that case, the settlement still lowers entry costs in all the ways noted above. Now suppose one instead believes that the rightsholders

18 Amended Settlement 6.2(b)(i); see also $\$ 6.1(\mathrm{a})$.

19 Leegin Creative Leather Products, Inc. v. PSKS, Inc., 551 U.S. 877, 896 (2007) ("in general, the interests of manufacturers and consumers are aligned with respect to retailer profit margins. The difference between the price a manufacturer charges retailers and the price retailers charge consumers represents part of the manufacturer's cost of distribution, which, like any other cost, the manufacturer usually desires to minimize.”); Elhauge 2008b, 441-442.

20 Amended Settlement $\$ 6.2(\mathrm{~b})(\mathrm{i})$. 
represented in the current class action could legally permit the Registry and Fiduciary to grant default licenses for their claimed and unclaimed books to Google's rivals, perhaps on the theory that rival licenses are inextricably intertwined with the licenses to Google. Then this provision would seem to affirmatively give the Registry and Fiduciary the power to license Google rivals without requiring later rightsholder permission, as long as the relevant rightsholders did not object. In this case, the settlement lowers the barriers for rivals even further, allowing rivals to get a default license similar to Google for all commercially unavailable books through agreements with the Registry and Fiduciary without incurring the costs of a class action at all.

In its initial Statement of Interest, the Department of Justice (DOJ) tentatively dismissed this second possibility on the grounds that the parties represented to it that "they believe the Registry would lack the power and ability to license copyrighted books without the consent of the copyright owner." ${ }^{21}$ But the views of Google and the class do not determine what the law actually permits. There are two possibilities. First, the parties might be incorrect in their prediction about what the law will permit. If so, then the provision does authorize the Registry and Fiduciary to grant default licenses to all commercially unavailable claimed or unclaimed books covered by the settlement. Second, the parties might be correct about what the law will permit. If so, then it is not the settlement agreement that is barring such licenses; it is the law that does not permit them. Either way, the settlement will have done all it legally could to authorize default licenses to rivals that parallel the default licenses the settlement grants to Google.

(4) Roadmap to Second Class Action. Even if the above methods were deemed incomplete or ineffective, the settlement would still, if approved, lower rival entry barriers by providing a roadmap by which rivals could use a similar class action vehicle to obtain those rights. Rivals could simply engage in copying efforts similar to Google, inviting a class action lawsuit that they would know (if this settlement were approved) they can settle on similar terms, perhaps with this settlement's Registry and Fiduciary, perhaps with other class action representatives that agree to create a second competing Registry and Fiduciary. If the second class action were controlled by the same forces who control the Registry and Fiduciary, they would have

21 Statement of Interest of the United States of America Regarding Proposed Class Settlement at 23, Authors Guild, Inc. v. Google Inc., S.D.N.Y. Case No. 05 CV 8136-DC (Sept. 18, 2009) [hereinafter "Initial DOJ Brief”]. 
incentives to license the rival in order to minimize Google's distribution markup. If it were not, then the second set of class action plaintiffs would be competitors of the Registry and Fiduciary with even stronger incentives to license a rival and undercut Google. If no class action were brought against the copying rivals, then the rivals would be even better off because they would be able to offer the same books as Google without incurring the same royalty costs. None of this is to deny that triggering a second class action would incur serious entry costs. The point is that the settlement does nothing to raise those costs but to the contrary, if approved, would somewhat lower those costs by reducing the risk that courts might not approve a similar settlement by rivals.

\subsection{The Critique of De Facto Monopoly and the Proper But-for-Baseline}

Critics argue that these entry barriers will remain insuperable for Google's rivals after the settlement because (1) outside of a second class action, it is impossible for rivals to get licenses for unclaimed books and infeasible to get simultaneous licenses over a comprehensive set of commercially unavailable claimed books; and (2) rivals would still regard a second class action as too costly and risky. The critics argue that this means the settlement will give Google a de facto exclusive license and monopoly in offering unclaimed books and a comprehensive set of commercially unavailable books. ${ }^{22}$ In its initial brief, the DOJ indicated tentative support for this position, but relied partly on a most favored nation clause in the initial settlement that has been cut from the amended settlement. ${ }^{23}$ It remains to be seen whether the DOJ will stick to this position even now that, with the elimination of the most favored nation clause, all the remaining obstacles to rival entry that the DOJ cited refer to factors that were not created by the settlement and would exist without it. I myself think that the most favored nations clause was always a red herring, because no persuasive analysis was ever offered about why it would deter rival entry (Elhauge 2009c, 4-5, 39-41; 2009a, 7). But regardless of whether one thought it was a red herring, eliminating this clause has

22 Amazon.com Objection to Proposed Settlement, Authors Guild, Inc. v.Google Inc., S.D.N.Y. Case No. 05 CV 8136-DC, at 1 (Sept. 1, 2009) [hereinafter “Amazon Initial Brief”]; Yahoo! Objection to Proposed Settlement, Authors Guild, Inc. v. Google Inc., S.D.N.Y. Case No. 05 CV 8136-DC, at 24-25 (Sept. 8, 2009) [hereinafter "Yahoo Initial Brief”]; Darnton 2009a; Fraser 2009, 2; Grimmelman Amicus Brief, Authors Guild, Inc. v. Google Inc., S.D.N.Y. Case No. 05 CV 8136-DC, at 9-10 (Sept. 3, 2009) [hereinafter "Grimmelmann Initial Brief”]; Grimmelmann 2009b, 1, 11-20; Picker 2009c, 385-386; Samuelson 2009a; Gibson 2008, A21.

23 Initial DOJ Brief at 23-24. 
usefully clarified that the objections of many critics are based on entry obstacles that would apply equally without the settlement, because these critics continue to object that the settlement creates a de facto exclusive license even though they can no longer point to any entry obstacle that was even arguably created or worsened by the settlement (Open Book Alliance 2009; Darnton 2009b; Grimmelmann 2009a; Picker 2009b, 2-3; Samuelson 2009b).

The de facto exclusive license critique has several problems. To begin with, it relies on three factual premises that must all be right for the critic's argument to work, and the accuracy of every one of them is debatable. (1) Perhaps the critics are right that the settlement cannot legally permit the Registry and Fiduciary to grant default licenses to Google's rivals, but if they are wrong in that legal premise, then the settlement does directly authorize such licensing. (2) Perhaps the critics are right that, absent Registry or Fiduciary licensing, rivals could never assemble a competing near-universal library without a second class action. But it also seems plausible that under the settlement: (a) almost all currently unclaimed books that have significant value would become claimed, and (b) rivals or the Registry could then assemble nearuniversal libraries by getting permissions from rightsholders of claimed books. The former is plausible because of Registry search and rightsholders' incentives to come forward, and the latter is plausible because the settlement greatly lowers the costs of identifying and contacting all claimed rightsholders. (3) Perhaps the critics are right that rivals would be unwilling to engage in conduct similar to Google's and risk triggering a second class action. But Google did so, and the risks of a rival doing so would only be lower if this settlement were approved because approval would resolve legal uncertainty about whether a similar rival settlement would get approved. Further, if the critics are right that the settlement would lead to monopoly pricing, then the rival gains from engaging in similar conduct would be high, higher than they were for Google, which probably never anticipated that digitizing books for snippet display in searches might trigger a class action settlement giving it default licensing rights to make profitable book sales. So if Google found the risk-reward tradeoff worth it despite a higher risk and less expected reward, one might think that a rival like Amazon, Microsoft, or Yahoo would also find it worthwhile after an approved settlement lowered the risk and raised the expected rewards.

Obviously, any of these three strategies would put these rivals behind the first-mover, Google, which is probably why these rivals have instead chosen to oppose the settlement directly and through the Open Book Alliance. 
But a first-mover advantage is not the same thing as a de facto monopoly, and the desire of rivals to avoid second-mover status is not grounds for antitrust invalidation.

In any event, we need not rest on disputed factual predictions, for what is even more interesting is that the critics' argument fails conceptually even if we grant them the benefit of each factual doubt. An assumption that critics are right on all their factual premises would not show that the settlement forecloses rivals or confers a de facto exclusive license, for the obstacles to rival entry to which the critics point are not caused by the settlement, but instead reflect independent entry barriers like transaction costs and copyright risks. The initial DOJ brief highlighted as much, concluding that "Google's competitors are unlikely to be able to obtain comparable rights independently. They would face the same problems ... that Google is seeking to surmount through the Settlement Proposal." ${ }^{24}$ In fact they would face lesser problems, not the "same problems," because the settlement lowers rivals' barriers in the ways described above, but assuming the DOJ is right that they would be the "same problems" only highlights that they are problems that the settlement seeks to surmount but did not create or worsen. Even if it turns out to be true that Google is the only firm that is willing or able to incur the costs and risks of a class action to trigger a settlement, that does not mean that the settlement forecloses anything or confers a de facto exclusive license. The foreclosure or de facto exclusivity would be provided by the unwillingness or inability of Google rivals to overcome entry barriers that the settlement did not create (and in fact lowers).

More important, if critics are right in their factual premise that these entry barriers are insuperable without this sort of class action settlement, it means that the but-for alternative to this settlement is a world where no firm offers either unclaimed books or a comprehensive set of commercially unavailable books. In other words, the critics' own premise confirms that this settlement provides a powerful procompetitive benefit—making

24 Initial DOJ Brief at 23; see also Yahoo Initial Brief at 24 ("Although nothing in the Proposed Settlement expressly prohibits the entry of any other potential market participant into the field of digital book scanning and searching, the structure of the Proposed Settlement ensures that the market is functionally closed to new entrants. Through the Proposed Settlement, Google has sidestepped the tremendously laborious process of negotiating with rights holders for individually tailored licensing deals. Any would-be competitor attempting to negotiate directly with each rights holder would be faced with insurmountable transaction costs and impossibility: a potential competitor simply cannot negotiate with every rights holder covered by the Proposed Settlement because of the large percentage of those rights holders that cannot be found.”). 
available books that could not be available without the settlement. ${ }^{25}$ Even if the critics are right that no Google rival could overcome the barriers to entry in a similar way, a market with one competitor is better than a market with none, because it increases market options and output from nothing to something, thus improving consumer welfare. If the critics are wrong, and other rivals can overcome the same entry barriers (perhaps because the settlement lowers them), then the settlement is even more procompetitive-creating a competitive market in digital distribution of a set of books that otherwise would not be offered at all.

Any ruling that antitrust law bars the sort of class action resolution proposed here would not reduce the relevant entry barriers. Instead, it would greatly increase entry barriers by preventing any firm-including Google and its rivals-from obtaining similar default rights. This would make it impossible for any firm to offer books that are unclaimed or insufficiently valuable to make it worthwhile for anyone (including the rightsholder) to incur the transaction costs of licensing, and would make it much more difficult for any firm to provide easy searchable access to most of the books that have been written. It would be perverse to employ antitrust law to require such an anticompetitive result.

Any claimed anticompetitive effects must be measured from the but-for baseline of what would happen without the settlement. Because commercially unavailable books are defined to be whatever set of books no seller finds worth offering for new sales in the future, and because nothing in the settlement increases the difficulty of offering any set of books, by definition any set of commercially unavailable books that Google can offer under the settlement will be books that would not be offered by anyone without the settlement.

The available evidence indicates that without this sort of class action settlement, no firm would offer widespread digital access to the set of in-copyright books that are currently commercially unavailable. Google itself did not attempt to do so before the settlement. Google just digitized these books for purposes of searches that gave snippets of text, which it argued was covered

25 Fraser 2009, 2 (acknowledging it would have been an "impossibility" for Google to have reached agreements with all rightsholders absent the class action settlement); Grimmelman Initial Brief at 9 (arguing without the settlement "Google itself could never, under any circumstances, have privately negotiated the permissions" to orphan books and that thus "no competitor will ever be able to obtain the necessary permissions to make competing uses of them."); Yahoo Initial Brief at 24. 
by the fair use doctrine, without making any effort to offer their full text. ${ }^{26}$ If the settlement were rejected and Google lost the litigation, it wouldn't be able to offer even those searches and snippets, and in the best case scenario where Google won the litigation, the fair use basis for its victory would limit Google to offering no more than those searches and snippets.

Nor has any other firm attempted to offer the full text of a similar set of books without going through a similar class action settlement process. In fact, the most likely potential entrants into the digital book market have affirmatively demonstrated that they would be unlikely to do so. Amazon began its "Search Inside the Book" feature in 2003 by scanning over 120,000 books for which it provides a partial preview, but it did not provide full digital text for any books or extend these partial displays to any out-of-print works or any books where it did not have prior publisher approval (Quint 2003). Microsoft attempted to assemble a library of 750,000 public domain and licensed commercially available works, but later abandoned the project in May 2008, explaining that its Live Book Search did not constitute a "sustainable business model" (Helft 2008). This suggests that even a giant like Microsoft finds it unprofitable to offer a digital library combining outof-copyright and commercially available books that does not include the incopyright, commercially unavailable books that would be hard or impossible to offer without a settlement like this. Microsoft's experience thus indicates that offering users the knowledge that they are searching through a complete or nearly-complete database of books may be a necessary precondition for a successful business model. Microsoft itself admitted as much when, in its online announcement that it was ending its Book Search project, it noted that it hoped to move to "more sustainable strategies" in which "our investments will help increase the discoverability of all the valuable content that resides in the world of books and scholarly publications" (Bing 2008). If so, this confirms the high procompetitive benefits of allowing a settlement that creates such a universal library. Either way, this indicates that without this settlement, neither Amazon nor Microsoft would provide anything resembling the near-universal access to digital books that this settlement provides.

But it does not matter whether this factual prediction is right or not. For if Amazon, Microsoft, or any Google rival does in the future offer any books

26 Joint Public FAQ from Authors Guild, Association of American Publishers \& Google, Question \# 6, available at http://books.google.com/googlebooks/agreement/faq.html; Conversation with Eric Schmidt hosted by Danny Sullivan, Search Engine Strategies Conference, August 9, 2006, available at http://www.google.com/press/podium/ses2006.html. 
for new sale that are not derived from the Google scanning project, then (even if those books are currently out of print) those books will become "commercially available," and then the settlement will by default exclude them from sale via Google. The settlement thus by definition does not give Google any default license or plausible de facto monopoly over any books that any rival would offer in the but-for world.

This but-for baseline has several implications. Even if the settlement gave Google the power to set monopoly prices for unclaimed books or for widespread digital access to commercially unavailable books (which as we shall see is contrary to fact), that would not be an anticompetitive effect because having a monopolist offer a product is better for consumer welfare than having no one offer a product. Nor is it at all unusual or improper if the first firm to overcome the entry barriers to offering a product reaps monopoly profits from doing so. That is regarded as their proper reward for investing to overcome those entry barriers and provide consumers with a desired product. ${ }^{27}$ Investing to be the first to overcome entry barriers is procompetitive, not anticompetitive, as long as the firm does not artificially increase entry barriers for later rivals. The first-mover's investment in overcoming those entry barriers makes consumers better off and restrains no competition that would have existed in the but-for world. That is especially true where, as here, the first-mover's investments in overcoming those entry barriers actually lower entry barriers for subsequent rivals.

In fact, the settlement is even more beneficial to consumers than suggested above because, even if no rival enters to provide these otherwise commercially unavailable books, this settlement would not give Google the power to set monopoly prices over any set of digital books because the settlement (1) gives individual rightsholders total freedom to price their books through Google or any Google rivals, and (2) requires that Google set prices for individual books and institutional subscriptions using algorithms that

27 Verizon Communications v. Law Offices of Curtis V. Trinko, 540 U.S. 398, 407 (2004) (“The mere possession of monopoly power, and the concomitant charging of monopoly prices, is not only not unlawful; it is an important element of the free-market system. The opportunity to charge monopoly prices — at least for a short period — is what attracts 'business acumen' in the first place; it induces risk taking that produces innovation and economic growth"); Elhauge 2003a, 332 ("when a firm uses proper conduct to create something sufficiently more valuable than existing market options to enjoy dominant market power, then any high prices it earns are the proper social reward for that creation ..."); Elhauge 2003b, 796, ("We thus must be careful not to act as if the purpose of antitrust laws were to eliminate monopoly profits themselves. Such profits are an extremely valuable inducement to the creation of better or cheaper products."). 
mimic competitive pricing. The details are explained in Part 3. Here, the important point to emphasize is that we should not infer, from the fact that the settlement would (even if rivals do not enter) create something as close as feasible to competitive market pricing, that the but-for baseline should be taken to be a fully competitive market in distributing these books, because that clearly would not exist without this settlement. Instead, without this settlement there would by definition be no market in unclaimed or commercially unavailable books, and thus no firm offering them or a nearuniversal library.

Accordingly, even if this settlement failed to eliminate all possible supracompetitive pricing, it would still be beneficial to consumer welfare because it would increase but-for future output of these books from nothing to something, although the future output would not be quite as high as it would be with full competitive pricing. If, as argued below, the settlement does provide full competitive pricing even without rival entry, then the results are even more beneficial to consumers. Alternatively, if rivals in fact do later provide these same otherwise commercially unavailable books, then encouraging settlements like this will lead to full competitive pricing for these books, which again would be even more beneficial to consumers. But these remarkable procompetitive effects do not alter the fact that the applicable antitrust test is whether the settlement improves consumer welfare from the but-for world, not whether it maximizes consumer welfare to the fullest extent conceivable. The DOJ's own guidelines stress that this but-for baseline applies when assessing the effects of horizontal business agreements, stating that "Rule of reason analysis focuses on the state of competition with, as compared to without, the relevant agreement" (Federal Trade Commission \& Department of Justice 2000, \$3.3).

\subsection{Responding to the Critique of the But-For Baseline}

Professor Randal Picker has critiqued this but-for baseline on two grounds, neither of which is well-founded. First, he equates the but-for baseline with a historical presettlement baseline, and argues that my reliance on a but-for baseline is thus incorrect because a cartel that starts just before a new product is introduced may result in more output than the past, but is still harmful (Picker 2009a, 4-6). This argument clearly attacks a straw man because antitrust has never understood a but-for baseline to equal a past baseline, and certainly I have never equated the two. The but-for baseline is what the market situation would be "but for" the alleged misconduct, and the whole 
reason antitrust uses this "but for" baseline is to distinguish it from what the market situation was in the past. ${ }^{28}$ Indeed, in my writing I have expressly cautioned against replacing the but-for baseline with a past baseline based on the pre-conduct world, stating that "using a past baseline may falsely suggest the conduct caused no damages even though the conduct did anticompetitively make prices higher than they would have been in the but-for world without that conduct" (Elhauge 2008b, 21). ${ }^{29}$

There is thus no tenable basis to claim, as Picker does, that by the but-for world I mean the "pre-settlement world" (Picker 2009a, 6). I don't. To the contrary, my argument is that the critics themselves claim that entry barriers unrelated to the settlement will in the future prevent any firm from providing commercially unavailable books without a Google-like settlement; thus, the critics' own claim means that the future "but for" world without the settlement would be a world where no firm can offer commercially unavailable books. ${ }^{30}$ While Picker is certainly correct that antitrust should not allow agreements simply because they result in higher output or lower prices than the past, antitrust should and does allow agreements that result in higher output and lower prices than would result in the but-for world without the challenged agreement. Disapproving a settlement that satisfies this but-for test would condemn us all to suffering lower output and higher prices than the output and prices we would enjoy from 2010 onward with settlement approval.

Second, Picker argues that a but-for baseline would approve an agreement that bundles an anticompetitive agreement with an unrelated

28 See, e.g., Maarten Pieter Schinkel 2008, 23 ("An essential part of assessing antitrust damages is to determine what would have been the market situation absent the competitive actssometimes referred to as the 'but-for' world."); Ariel Katz 2007, 882 ("Antitrust looks at the effect of a specific restraint or conduct on the firm's (or the involved firms') ability to set their price higher or lower relative to a relevant benchmark, which should generally be the price (or other relevant variable) that would have existed but for the impugned conduct."); Roger D. Blair \& Christine A. Piette 2006, 413 ("In general, an antitrust plaintiff should recover the difference between its actual economic condition and the condition it would have enjoyed but for the antitrust violation.").

29 See also Elhauge 2008b, 414, arguing against using a baseline of prices before an alleged anticompetitive program because if costs or market power would otherwise have decreased over time, then the "but-for price that would have been charged in a later period would be lower than the price that was charged in the period before the program, and thus the pre-program price would be too high a baseline."

30 For reasons noted above, I agree that without approval of class action settlements like this one, no firm would offer the set of books that would be commercially unavailable in the but-for world, but it seems to me quite plausible that rivals would offer those books with approval of this settlement because the settlement lowers rival entry barriers in various ways. 
procompetitive agreement if the net effects are positive (2009a, 5-7). But, once again, this misconstrues the but-for baseline, which judges each separable agreement separately. If agreement on one provision has anticompetitive effects and does not contribute to the procompetitive effects of the rest of the agreement, then it is separable and the but-for test would condemn the anticompetitive provision because the procompetitive portions of the agreement would go forward in the but-for world without the separable anticompetitive provision. The assertion that the but-for test presupposes that anything grouped in one contract has to be treated as a unit is thus another straw man and not at all a premise used in my analysis.

Here, the critics are condemning provisions that, viewed separately, have clear procompetitive effects because they increase output and decrease prices from but-for levels. Consider the four main critiques the objectors have made.

Their first critique argues that a class action settlement cannot give Google a nonexclusive default license to sell commercially unavailable books, partly because copyright law makes it illegal to copy without express rightsholder authorization. ${ }^{31}$ This argument strikes me as quite dubious: the whole point of class actions is to give class counsel abilities to act on behalf of class members, and class actions often authorize things on behalf of people who otherwise legally have to give express authorization. ${ }^{32}$ After all, waivers of legal claims under tort, antitrust, or securities law must also generally be express, and no one has ever thought this means that tort, antitrust, and securities claims cannot be resolved by opt-out class actions. In any event, the default license granted by the settlement is necessary to achieve the relevant procompetitive effects because without a default license, as the critics themselves argue, no firm could offer unclaimed and commercially unavailable books. Thus, in the but-for world, holders of copyrights in unclaimed and commercially unavailable books would get zero royalties and readers would be deprived of access to their books.

31 Amazon Initial Brief at 31-34; Microsoft Objection to Proposed Settlement, Authors Guild, Inc. v. Google Inc., S.D.N.Y. Case No. 05 CV 8136-DC, at 3, 6 (Sept. 8, 2009) [hereinafter "Microsoft Initial Brief"]; Open Book Alliance Objection to Proposed Settlement, Authors Guild, Inc. v. Google Inc., S.D.N.Y. Case No. 05 CV 8136-DC, at 2 (Sept. 8, 2009) [hereinafter “Open Book Alliance Initial Brief”]; Yahoo Initial Brief at 7-10; Peters 2009, 3, 5-8.

32 Although the critics repeatedly refer to the default license as a "compulsory license," this characterization is incorrect. Rightsholders can opt out of the settlement, or even if they do not, can opt out of the license at any time in the future, and indeed can opt in, and out, and back, and forth of the license and any separable license features at any time. See infra Part 3. 
Given that nothing in the copyright statute states that it prohibits waivers via class action, it is hard to see why, despite this statutory silence, a copyright provision that was designed to protect copyright owners should be interpreted to require harming both copyright owners (by lessening their royalties) and the public (by lessening their access to books). As Professor Grimmelman notes, the twin purposes of copyright law are to reward authors and maximize the creative works actually made available to the public. ${ }^{33}$ It seems quite perverse to interpret statutory silence to thwart both of the statute's purposes. It seems equally perverse to argue that sound class action procedure under Rule 23 requires an interpretation that, by precluding default licenses, harms unknown rightsholders in the name of protecting their rights, and indeed harms all class members and the class defendant, as well as the public interest in accessing these books. ${ }^{34}$ Even if copyright law and Rule 23 did require such a perverse result, it is clear that antitrust law does not, because the nonexclusive default license over commercially unavailable books, standing alone, has strong procompetitive effects.

The second critique is that the settlement does not go far enough because it does not also authorize default licenses for Google's rivals. ${ }^{35}$ This second critique is quite inconsistent with the first one. If a settlement of litigation between a class of rightsholders and Google cannot, as critics argue, grant default licenses to Google under copyright law or Rule 23, then a fortiori such a settlement cannot grant default licenses to rivals that were not even involved

33 Grimmelman Initial Brief at 2.

34 Many critics argued that a class settlement must be limited to past conduct and could not provide forward-looking licenses. See Amazon Initial Brief at 1-2, 34-40; Microsoft Initial Brief at 4, 21-25; Yahoo Initial Brief at 17-19. However, the DOJ rejected this critics' position on the ground that a "class of copyright holders may be able to settle a lawsuit over past conduct by licensing a broader range of conduct to obtain global 'copyright peace."' Initial DOJ Brief at 6. The DOJ's Rule 23 concerns were instead whether possible class conflict issues might be raised because the class settlement (1) covered rightholders from certain objecting foreign nations, (2) had the Registry act for both known and unknown rightsholders, (3) allowed expansion to unspecified future revenue models, and (4) provided that royalties earned on unclaimed books could inure to the benefit of the Registry and known rightsholders if the unknown rightsholders were never found. See id. at 6-13. Whatever the merits of those initial concerns, they seem to be addressed by the amended settlement, which (1) excludes books that were registered in the United States or published in the United Kingdom, Canada, or Australia, (2) creates an independent fiduciary to represent unknown rightsholders, (3) specifies the future revenue models, and (4) prevents royalties for unclaimed books from ever inuring to the benefit of the Registry or known rightsholders. See Amended Settlement $\$ \$ 1.19,3.2(\mathrm{e})(\mathrm{i}), 3.10(\mathrm{e})(\mathrm{iii})$, 4.2(c)(i), 4.5(b)(ii)., 4.7, 6.2(b)(i), 6.3(a)(3).

35 Initial DOJ Brief at 25 \& n.10; Grimmelman 2009a; Open Book Alliance Initial Brief at 29-31; Picker 2009b, 3, 10-12. 
in the litigation. If the critics really believe that granting default licenses is illegal under copyright law or Rule 23, then they should oppose granting default licenses to anyone, and be prepared to defend an interpretation of those laws that manages to harm not only copyright owners and users, but also all class members, the class defendant, and the public interest. If they really don't believe that granting default licenses is illegal under those laws, then they shouldn't raise an invalid objection to try to squeeze a better deal out of Google and the rightsholders. Anyone who argues that the settlement should authorize default licenses to rivals has implicitly conceded that authorizing default licenses to Google does not violate copyright law or Rule 23.

Moreover, this second critique never comes to grips with the fact that the settlement already authorizes the Registry and Fiduciary to license Google's rivals "to the extent permitted by law." So the only way the settlement doesn't authorize licensing rivals would be if it turns out to be illegal to do so. Do the critics want the settlement to authorize licensing rivals even if that is illegal? That would be bizarre and, in any event, ineffective. Or, more likely, do the critics want no one to get default licenses unless the settlement can legally authorize default licenses for both Google and its rivals? That seems a more plausible reading of their position, but would clearly violate the but-for test because a world where Google alone can offer unclaimed and commercially unavailable books is clearly better for consumer welfare than a world where no one can, especially given that the settlement provides for competitive pricing through Google.

Even if we ignore the fact that the settlement does authorize licensing rivals if it is legal to do so, this second critique does not support Professor Picker's bundling claim. The second critique does not show that nonexclusive default licenses to Google have anticompetitive effects that the parties are attempting to bundle with other provisions that have procompetitive effects. The nonexclusive default licenses to Google over commercially unavailable books, standing alone, have pure procompetitive effects over the but-for baseline, without bundling them with any other provisions. The second critique instead claims that the court should disapprove nonexclusive default licenses that do enhance consumer welfare (compared to the but-for baseline) unless the parties add more nonexclusive default licenses that would enhance consumer welfare even further.

It is this move that is improper under antitrust's but-for standard because it is not an antitrust violation to enter into an agreement that benefits consumer welfare on the theory that another agreement could have benefitted 
consumer welfare even more. ${ }^{36}$ The reason is plain to see: if the critics' implicit antitrust standard were the law, then every single joint venture that charged anything for its product would be an antitrust violation because it would benefit consumer welfare even more if the joint venture offered its product for free. And if that were the law, no one would propose joint ventures that benefit consumer welfare at all. This free-product baseline is not only the logical implication of the critics' implicit baseline, but is sometimes invoked more explicitly. At a conference I attended about this settlement, some opponents who complained that the settlement treated rightsholders unfairly made clear that their objections would go away if the settlement provided unclaimed books for free. This position begs the question of why rightsholders would be better off if required to take the zero royalties they would get on free books rather than the positive royalties they would get under the settlement. More important for present purposes, this position indicates that some critics are relying on a free access baseline that, while a common norm among many Internet enthusiasts, is not the but-for baseline required by antitrust law.

Nor do I know of any case that has held that authorities can disapprove a settlement between two parties whose provisions each benefit the public interest on the ground that the settlement could have added additional benefits to the public interest. The power to protect against settlements that harm the public interest is not a license to threaten settlement disapproval in order to expropriate as much from the settling parties as possible, even if the expropriation is done in the name of benefitting the public. Distorting the settlement approval process in that fashion is not in the long run best interests of the public interest, for at least two reasons. First, the authorities might get the game theory wrong, blowing up settlements and preventing any benefit to the public interest. Second, expropriating as much as possible of the joint gains will discourage ex ante investments to create those joint gains in the first place.

The third major critique has been that the provisions specifying default prices and royalties for commercially unavailable books amount to

36 Nor could one say that this second critique is relying on the less restrictive alternative test because that test only applies when an agreement restrains competition to further a procompetitive justification that could equally be advanced through some alternative that is less restraining of competition. Here, the nonexclusive default licenses to Google do not restrain competition at all; the critique is instead that independent factors restrain rival entry and that the settlement does not fully overcome those factors for rivals. Thus, the second critique is not applying a less restrictive alternative test: it is applying a "more beneficial alternative" test, which fails for the reasons noted in text. 
illegal horizontal price-fixing, ${ }^{37}$ even though the default prices are set with a competition-mimicking algorithm and any rightsholder can competitively set its own price and would have incentives to do so if supracompetitive prices were set. This argument is wrong for many reasons detailed in Part 3, but for present purposes the important point is that these provisions are not separable from the default licenses because one cannot have a default license without some default price and royalty. Thus, the only way to avoid default prices and royalties would be not to have default licenses at all, making it impossible to offer unclaimed books and infeasible to offer books that by definition would otherwise be commercially unavailable. Condemnation of these provisions would thus clearly harm consumer welfare relative to the correct but-for standard. This application of the but-for test does not at all depend on an argument, as Professor Picker asserts, that these provisions have anticompetitive effects that are outweighed by other procompetitive effects of the settlement.

In its initial brief, the DOJ challenged the need for default pricing and royalties, stating: “The parties' contention that this kind of industry-wide pricing mechanism is necessary to create a vibrant market for digital books is difficult to reconcile with the facts on the ground. Millions of digital books are already available for purchase, including growing numbers of out-of-print books, as a result of bilateral negotiations between distributors and individual rightsholders." ${ }^{38}$ But this DOJ statement misses the point that the settlement does not grant default licenses for any book that is commercially available for new sale from any source other than the Google scan, whether or not the book is out of print in the physical sense. ${ }^{39}$ So the settlement by definition provides no default license or prices or royalties for the millions of digital books that are-or will be-available for purchase from sources other than the Google scan covered by the settlement. The DOJ's initial brief also asserted that the provisions on default prices and royalties were not "reasonably necessary to achieve the stated benefit of the Proposed Settlement-breathing new commercial life into millions

37 Initial DOJ Brief at 17-21; Amazon Initial Brief at 1, 18-24, 30; Open Book Alliance Initial Brief at 2, 27-28; Yahoo Initial Brief at 22-23; Fraser 2009, 15-17; Picker 2009c, 383, 385, 398, 408; Picker 2009b, 5-6.

38 Initial DOJ Brief at 22.

39 Amended Settlement $\$ 1.31$ (defining “commercially available”); infra note _ (collecting provisions that create default license for books that are not commercially available). 
of long-forgotten, commercially unavailable works." ${ }^{40}$ But it provided no support for this assertion, which seems directly contrary to the DOJ's point on the very next page that without similar default licenses rivals would be unable to offer unclaimed books. ${ }^{41}$ The latter is more persuasive because without default terms on prices and royalties, a firm would have to obtain the consent of the rightsholder on the price and royalty, and as the DOJ notes "consent cannot be obtained from the owners of orphan works." 42 Nor, without default licenses, would anyone find it worthwhile to negotiate licenses for other commercially unavailable books given that, by definition, those books would be commercially unavailable without such default licenses.

The fourth critique has been that the settlement covers both claimed and unclaimed books, and should jettison the latter category (Picker 2009c, 383, 409). This objection to settlement bundling fails because, as shown in the next Part, the settlement is enormously procompetitive for each and every category of books, viewed entirely separately. Further, unbundling the book categories would affirmatively reduce the procompetitive effects of the settlement without alleviating the supposed anticompetitive concerns. After all, a great deal of the value of this settlement comes from creating a common searchable database for locating and viewing a near-universal library of books. The whole is more valuable than the sum of its parts, and it is that collective value that makes it commercially feasible to offer books that otherwise would be commercially unavailable. Moreover, if unclaimed books were separated, unknown rightsholders would not have the same incentives to register to get the advantages of being a known rightsholder and there would not be a commonly funded Registry to help locate them. To the extent that unknown rightsholders are a problem, separating them would prevent the settlement from reducing the size of that problem. Nor would separating them help alleviate anticompetitive concerns because a separate settlement that licensed unclaimed books would still have to set some price for those books, and it is hard to know how one could do much better than requiring a pricing mechanism designed to mimic how their unknown rightsholders would have competitively set prices if they had all the information Google will have.

\footnotetext{
40 Initial DOJ Brief at 22.

41 Id. at 23.

42 Id. at 23 .
} 


\subsection{The Alternative of Waiting for Congress}

Some suggest that the settlement should be disapproved because instead Congress should or likely would enact orphan works legislation..$^{43}$ But I have never heard of a case where an agreement with procompetitive effects was rejected on the ground that the but-for world should or would feature new legislation that will achieve those procompetitive benefits. And with good reason.

First, it is presumptuous for any court to assume what Congress will do. Waiting for legislative action can be like waiting for Godot. It may never come. People have been waiting for years for orphan works legislation, and it has not happened yet. If legislation does come, it may be in an unexpected or limited form. No one can be sure that any new legislation would give readers the access to commercially unavailable books that the settlement will offer. Even if the new legislation solved the problem of unclaimed books, it might not provide the default licenses necessary to restore commercial viability to claimed books that would otherwise be commercially unavailable.

Second, nothing in the settlement in any way precludes effective congressional action. If, in the but-for world, Congress would enact legislation giving many firms an ability to distribute books that are unclaimed or otherwise commercially unavailable, then Congress can and would still do so with the settlement. Because every right given by the settlement is nonexclusive, it in no way impedes any congressional effort to authorize the distribution of unclaimed or commercially unavailable books. In short, if effective new legislation does come, the settlement causes no harm. But if effective new legislation doesn't come, then blocking the settlement will consign to oblivion all unclaimed and commercially unavailable books.

Third, an approved settlement would, if anything, make congressional action more likely for other reasons. To begin with, it would make legislative action administratively easier because it creates an administrative apparatus, the Registry and Fiduciary, that Congress can use to grant licensing rights and distribute royalties on unclaimed books. Moreover, the settlement would lessen the objection, which might otherwise be raised to orphan books legislation, that unclaimed books cannot be sold without express rightsholder consent, because those books would already be sold. Finally, the settlement would

43 Amazon Initial Brief at 7-15; Microsoft Initial Brief at 3-4, 6-16; Open Book Alliance 2009; Yahoo Initial Brief at 2-7; Grimmelman Initial Brief at 18-19; Darnton 2009b; Peters 2009, 7-8. 
create powerful interest groups, supported by Google's rivals, favoring orphan works legislation, and Google has already pledged to support it as well.

In short, it would be risky to block the settlement based on speculation that Congress might perhaps do better, unnecessary to do so given that Congress could equally take any desirable action with the settlement, and counterproductive to do so given that blocking the settlement makes Congressional action less likely. It is thus not surprising that the but-for test has never been interpreted to mean that an agreement to overcome entry barriers should be prohibited because new legislation might overcome those same entry barriers a bit more broadly.

\section{THE STRONG PROCOMPETITIVE EFFECTS AND LACK OF ANTICOMPETITIVE EFFECTS}

Relative to the proper but-for baseline, the settlement has remarkably strong procompetitive effects and no anticompetitive effects. The analysis is easiest to follow if one takes each category of books in turn.

\subsection{Out-of-Copyright Books}

Although the settlement nominally does not apply to out-of-copyright books, it does affect them for reasons noted above. In particular, the settlement creates and funds a process that will increase the number of books that are effectively in the public domain by clarifying that they are out of copyright. The fact that the settlement clarifies their status also encourages Google to digitize them for reader access, as does the fact that the rest of the settlement gives Google the opportunity to create a universal searchable library. Google allows searchers to read, download, and print outof-copyright books for free. ${ }^{44}$ Creating an expanded, digitized set of free out-of-copyright books has several procompetitive effects.

Lower Reader Costs. The Google Book Search program dramatically lowers the costs of finding and owning out-of-copyright books. Without the Google Book Search program, it might be difficult, if not impossible, to discover whether an out-of-copyright book might be of interest. Once discovered, copies of the book might be impossible or costly to find and buy in the used-book market if they are rare. Even if they are available in a library, it

44 Joint Public FAQ from Authors Guild, Association of American Publishers \& Google, Question \# 9, available at http://books.google.com/googlebooks/agreement/faq.html. 
might costly to travel to a library that has them, the library might not allow duplication of rare books, and any allowed photocopies may be of poor quality. Further, rummaging through used-book stores or libraries imposes considerable delay. With the Google Book Search program, anyone online can easily search the full text of all out-of-copyright books to find which books are of interest, and immediately read, download, or print them for free. Because the settlement expands the set of books that are available as digitized out-of-copyright books, it lowers the costs and delays of buying and reading these books to zero, and thus increases output, whether measured in number of book copies or reading experiences.

Lower Rival Costs. The settlement lowers the costs for any Google rivals who wish to also offer out-of-copyright books, as explained above, by allowing rivals to buy digitized copies of these books from fully participating libraries and by clarifying which books are in fact out of copyright. Because Google offers these books for free, this increased distribution competition cannot further reduce book prices, but it can make the books available in even more platforms and help constrain any Google advertising prices.

Lower Used Book Prices for Out-of-Copyright Books. Expanding the set of out-of-copyright books that are available for free should exert downward pressure on used book prices for these books. This will benefit even consumers who do not want digital books and only like to read books with printed pages.

Lower Prices for Competing In-Copyright Books. The expanded free availability of all out-of-copyright books can also put downward pressure on licensing fees and book prices for some in-copyright books. For example, readers who want great or fun literature may find many out-of-copyright books that, at a price of zero, they are willing to read instead of buying an in-copyright book. Thus, expanding the free and easy availability of outof-copyright books can also be expected to have procompetitive effects on prices for the remaining categories of books.

No Anticompetitive Effect. The settlement has no anticompetitive effect on out-of-copyright books, and as far as I know no critic has even suggested any might exist. The effect on out-of-copyright books is thus solely and unremittingly procompetitive.

\subsection{Commercially Available Books}

Resolving Unclear Digital Rights. Currently, it is often unclear-even for some commercially available books-whether the author or publisher 
holds digital rights because their contractual language frequently did not anticipate digitization. ${ }^{45}$ This can lead to an unfortunate state of affairs where neither the author nor publisher is willing to give a digital license because the profits from doing so are smaller than the risk of paying statutory damages if the other is ultimately held to have the right. However, each would be willing to sue if the book were published without their permission, given the prospect of collecting those statutory damages. The settlement lowers these transaction and risk-bearing costs by providing a clear process by which, despite such uncertainty, decisions can be made about whether to allow a book to be included in the digital database and displayed or sold through Google. ${ }^{46}$ This makes it much easier to license these books for digital sale, and thus increases the output of these books. This is a clear procompetitive benefit with no anticompetitive effect.

Allowing Book Searches. The settlement further allows Google to digitize all books published before January 5, 2009, thus making them searchable by readers, and to provide indexing information about the books found in searches, unless the rightsholder chooses to remove the book from the Google database. ${ }^{47}$ Google then uses this information to direct searchers to bookstores or local libraries where the books are available. ${ }^{48}$ This is a clearly procompetitive result with no anticompetitive effect. It increases the ability of buyers to find which books they want and where to buy them, without in any way impeding competition among book sellers. If rightsholders prefer not to promote their books in this way, they can always remove them from the searchable database. Without the settlement, Google might have lost the litigation and been unable to digitize these books and make them searchable unless it affirmatively secured permission from each rightsholder, which would have imposed prohibitive costs.

45 Random House v. Rosetta Books, LLC, 150 F. Supp. 2 d 613 (S.D.N.Y. 2001), aff'd per curiam, 283 F.3d 490 (2d Cir. 2002) (finding that contractual language that gives the right to "print" a book does not give a right to make digital copies).

46 Amended Settlement Attachment A, Articles V-VI.

47 Amended Settlement $\$ 3.1$ (a) (allowing digitization of all books); $\$ 3.2(\mathrm{~b})$ (making all in- print books "no display" by default); $\$ 3.4($ a) (allowing Google to make "non-display" uses of "no display books"); $\$ 1.94$ (defining "non-display uses" to allow searches of the full text and providing indexing information but not displaying any content of the books); \$3.5(a)(i) (allowing rightsholder to remove book from digitized database).

48 Google 2009: "if the book you want is available in a bookstore or nearby library, we'll continue to point you to those resources, as we've always done." 
Allowing Display and Nonexclusive Sale Through Google. By default, actual content from commercially available books can neither be displayed nor sold by Google. ${ }^{49}$ However, the settlement provides that rightsholders may at any time choose to allow Google to display free preview portions of their commercially available books. ${ }^{50}$ If the rightsholder chooses to allow display, then its book is by default available for nonexclusive sale on Google both through individual consumer purchase and institutional subscriptions, but a rightsholder may at any time choose to make a displayed commercially available book unavailable for sale by Google through either or both means. ${ }^{51}$ Likewise, Google can exclude a book from any display uses or sales for any "non-editorial" reason. ${ }^{52}$ By default, books sold through Google are fully viewable online, but can be cut and pasted only 4 pages at a time and printed only 20 pages a time, although rightsholders can remove those limits to permit as much copying and printing of their books as they

49 Amended Settlement $\$ 3.2$ (b) (making all commercially available books "no display" by default); $\$ 3.4(\mathrm{a})$ (allowing Google to make "non-display" uses of "no display books"); $\$ 1.94$ ("Non-Display Uses" means uses that do not display expression from Digital Copies of Books or Inserts to the public").

50 Amended Settlement $\$ 3.4($ b) ("Rightsholders of Books may ... direct Google or the Registry to change the classification of a No Display Book to a Display Book, or to include any or all of their No Display Books in one or more the Display Uses"); $\$ 1.52$ (“Display Uses' means the following: Snippet Display, Front Matter Display, Access Uses and Preview Uses"). Although $\$ 3.2(\mathrm{e})$ (i) provides that the Registry can also change a book to display status, Amended Settlement Attachment A $\$ 5.1$ provides that "for an In-Print Book, both the Author and the Publisher of such Book must agree, in accordance with the following procedure, that Google may make one or more Display Uses of the Book.” Thus, it appears that \$3.2(e)(i) allows the Registry to change commercially available books to display status only with prior approval of the rightsholders, thus allowing a convenient way for the rightsholders to communicate to Google through the Registry without giving the Registry a right to act without their permission.

51 Amended Settlement $\$ 1.52$ (“display uses" includes “access uses"); $\$ 1.1$ ("access uses" means "Institutional Subscriptions, Consumer Purchase and the Public Access Service"); §3.5(b)(i) (allowing a rightsholder to remove its book from any "display use" or any "revenue model"); $\$ 1.131$ (defining "revenue model" to include "Institutional Subscriptions, Consumer Purchases, Advertising Uses, Public Access Service and any other revenue models”); \$3.5(b)(iii) (providing that commercially available books are exempt from the "coupling requirement" that requires rightsholders of commercially unavailable books to make any book they make available for consumer purchase also available for institutional subscription); $\$ 2.4$ (providing that any authorizations a rightsholder gives Google are "non-exclusive only" and do not preclude "Rightsholder's right to authorize ... direct competitors of Google, to use his, her or its Books or Inserts in any way, including ways identical to those provided for under this Settlement Agreement.")

52 Amended Settlement $\$ 3.7(\mathrm{e})$. 
want, including giving a Creative Commons License. ${ }^{53}$ For any sales under the settlement, Google by default pays rightsholders 63 percent of revenues from sales and advertising associated with their books, ${ }^{54}$ but either Google or any rightsholder can decline to have a book sold through Google unless the other side agrees to change that default royalty rate. ${ }^{55}$

Institutional subscriptions cover both commercially available and unavailable books, and raise special issues that will be discussed in a separate section below. Consumer purchases are book by book, and each rightsholder can (1) set whatever price it wants (including \$0) for sale of its book through Google, (2) allow Google to set a price for its book using a settlement algorithm that is designed to mimic the competitive prices that rightsholders would set if they had Google's information, or (3) use a mixed strategy of allowing Google to set its book price using the settlement algorithm subject to maximums or minimums specified by the rightsholder. ${ }^{56}$ Rightsholders can also switch back and forth between these three pricing methods for consumer purchases through Google. ${ }^{57}$ Further, given the above provisions, rightsholders can also (1) sell through a Google rival instead of through Google, (2) bargain with Google to sell through Google at a royalty rate different from the default offered under the settlement;

53 Amended Settlement $\$ 1.35$ (“consumer purchase” includes full viewing online); $\$ 1.77$ (same for “institutional subscription”); \$4.1(d) (setting default limits on printing and copying books available in institutional subscriptions); $\$ 4.2(\mathrm{a})$ (same for sales through individual book purchase); $\$ 3.3(\mathrm{~g})$ (allowing rightsholder to lift any of those limits).

54 Amended Settlement $\$ 2.1$ (a) (standard revenue split is 70 percent of revenue minus 10 percent for operating costs, which comes to 63 percent); $\$ 4.5$ (a) (providing that this 63 percent split by default applies to both purchase and advertising revenue); $\$ 4.7$ (providing that this 63 percent split default applies to the possible future revenue models of print on demand, file download, or consumer subscriptions). Google also pays $\$ 60$ per book to rightsholders whose books were scanned before May 5, 2009. Settlement $\$ 2.1(\mathrm{~b})$.

55 Amended Settlement $\$ 4.5$ (a)(iii). Although $\$ 4.5(\mathrm{a})$ (iii) is a new provision in the Amended Settlement that makes this power explicit for commercially available books, this power already seemed implicit for all books in that makes this power explicit for commercially available books, this power already seemed implicit for all books in the original settlement, which allowed rightsholders to exclude books, $\$ 3.5(\mathrm{~b})$, and allowed Google to decline to distribute books for "non-editorial reasons," $\$ 3.7(\mathrm{e})$, both of which were powers that could be used to renegotiate the royalty rate. But the amendment removed any doubt about the issue for commercially available books.

56 Amended Settlement $\$ 4.2$ (b), (c)(i). To prevent any fear of possible oligopolistic coordination, the Registry cannot share algorithm prices with anyone other than the rightsholder of the individual book or reveal whether a public price is an algorithm price. Id. $\$ 4.2$ (c)(iii).

57 Amended Settlement $\$ 4.5(\mathrm{~b})$ (ii), (c) (i). 
(3) simultaneously sell the same book through Google and a Google rival at any price they wish, and (4) even take advantage of the ability to display previews of their books on Google, but have Google direct potential buyers to a Google rival rather than allowing sale by Google. For its part, Google not only can drop any book for any noneditorial reason, including a desire for a lower royalty rate than the settlement default, but also can unilaterally discount the list price set by the rightsholder by up to Google's 37 percent revenue share at any time. ${ }^{58}$

These settlement provisions have strong procompetitive effects. They add a new nonexclusive promotional platform by which buyers can more easily identify the books they want and purchase them either through Google or its rivals in digital or nondigital form. These provisions do not take away or impede any existing vehicles for promoting or selling commercially available books, but add a new one with lower distribution costs

58 Amended Settlement $\$ \$ 4.5$ (b) (i). In response to a DOJ objection, this last provision amended an original provision that allowed Google to make only "temporary" discounts. See Initial DOJ Brief at 21-22. This change is interesting because the DOJ intervention here required dropping a provision that effectively involved vertical minimum price-fixing because the original provision allowed each individual rightsholder to set both the wholesale and (long term) resale price for its book. This may be the first instance of U.S. agency enforcement against vertical pricefixing in a long time, suggesting some backlash to the Supreme Court decision in Leegin. What is unclear is whether this DOJ intervention was desirable. Vertical price-fixing might have procompetitive justifications like reducing free-riding on services. Leegin, 551 U.S. at 890-891. Here, one might well imagine that rightsholders would want to provide a distribution margin large enough to encourage physical booksellers to hire knowledgeable clerks or display their books in attractive spaces and to encourage Internet booksellers to provide good promotion services or interesting advice on books. Trying to encourage such services could be undermined if book buyers could get the benefit of those services and then hop right over to Google to buy the book at a lower price that does not cover the costs of those services. Moreover, the two main anticompetitive concerns about vertical price-fixing are that it might reflect a cartel among downstream retailers or facilitate oligopolistic coordination among upstream providers. See Leegin, 551 U.S. at 892-93. Neither seemed likely here because Google was the only retailer covered and because book markets are rarely oligopolistic and temporary discounting can undermine oligopolistic coordination anyway. The initial DOJ brief did not consider any procompetitive justification or the likelihood of actual anticompetitive effects, but simply treated this provision as per se illegal, apparently on the assumption that it amounted to a horizontal agreement among rightsholders not to discount their book prices. See Initial DOJ Brief at 21-22. This characterization seems incorrect because the individual rightsholders always remained free to discount their book prices by however much they wanted; it was Google that was (in the original settlement) restricted in its ability to permanently discount from the resale price set by each individual rightsholder. However, it was not clear that the parties ever presented a persuasive procompetitive justification for this provision, in which case summary condemnation might be merited even under Leegin, which held only that vertical price-fixing could not be condemned without at least considering procompetitive justifications. In any event, the amendment eliminated the issue. 
and without any shipping delay. These provisions should thus increase the output of commercially available books. Even for books that rightsholders choose to make available only in nondigital form, these provisions will increase the degree to which purchase decisions reflect true consumer preferences because they allow Google searches that expose users to books irrespective of print volume or advertising expenditure and that lower the transaction costs in searching for obscure commercially available works. Economists have shown that websites like Amazon.com that made it easier to search online for a greater variety of books led to an annual increase in consumer welfare of $\$ 731$ million- $\$ 1.03$ billion, which they note is $7-10$ times greater than the consumer welfare gain from the increased competition and lower costs resulting from the Internet (Brynjolfsson, Hu, \& Smith 2003). Because Google Book Search will make it even easier to search for a greater variety of books than are available on Amazon, we can anticipate that it will advance this trend. For titles that rightsholders permit Google to sell, the procompetitive impact on distribution competition will be direct and even greater: Google will become a new competitor to existing retailers, precipitating a reduction in prices, particularly given the low overhead costs associated with digital sales.

These provisions have no anticompetitive effects given that they leave individual rightsholders entirely unrestrained from selling at any price and through any distributor or multiple distributors. Some, including the initial DOJ brief, have objected that (a) the settlement terms allowing Google to set default prices using a settlement algorithm amount to horizontal price-fixing on retail prices and (b) the settlement's default royalty rate amounts to horizontal price-fixing on wholesale prices. ${ }^{59}$ But these critiques are mistaken on several grounds, and it is not clear that the DOJ will stick to its initial view now that amendments to the settlement remove any doubt that (1) the algorithm price is competition mimicking, (2) Google and rightsholders can renegotiate the default royalty split, and (3) Google can discount the book price by its revenue share at any time. However, other critics have suggested that these changes do not or might not eliminate their concerns (Picker 2009b, 5-6). Thus, it is worth explaining in detail why these critiques are mistaken.

First, there is no horizontal agreement among the rightsholders because none of them have agreed with each other that they will accept Google's

59 Initial DOJ Brief at 17-22; Amazon Initial Brief at 1, 18-24, 30; Yahoo Initial Brief at 22-23; Fraser 2009, 15-17; Picker 2009c, 383, 385, 398, 408. 
algorithm price and royalty split. All the settlement provides is a nonexclusive offer by Google to display and sell their books at certain prices with a 63 percent royalty split, which by default has been rejected by all rightsholders of commercially available books. Thus, the settlement could in no way be deemed even a tentative horizontal agreement on prices or royalties for commercially available books. Rather the settlement requires each rightsholder to individually decide whether it wants to (1) accept the offer, in which case it is still free to sell at any other price or royalty through a Google rival; (2) reject the offer and instead sell through a Google rival at any price or royalty it wishes, (3) accept the Google offer to sell its book but unilaterally set the retail price for that book itself; and (4) reject Google's standard form offer on royalty rates and try to bargain for a different royalty rate from Google; (5) accept the Google offer to display its book but not to sell its book; and/or (6) accept the Google offer to sell its commercially available book through consumer purchase but not through institutional subscription, or vice versa. To the extent multiple rightsholders eventually accept Google's offer, this does not create a horizontal agreement among them to do so, but rather a series of vertical agreements between each rightsholder and Google whereby the individual rightsholder agreed to Google's standard form offer. Nor is the default royalty rate a horizontal agreement among rightsholders on royalties that is binding on Google because Google can drop any book whose rightsholder does not agree to a different royalty rate.

For whatever set of rightsholders eventually choose to distribute their books through Google, the situation is just like any case where a distributor offers many suppliers an opportunity to sell through the distributor at a given price and commission, and many suppliers agree. In such cases, we have a series of vertical agreements on the price and commission, but no horizontal agreement. Further, because the opportunity is nonexclusive, we have the sort of vertical agreements that solely affect distribution through that particular distributor and have no exclusionary effect on rivals of that distributor.

The Initial DOJ Brief rejected this vertical categorization on the ground that "Class representatives-who compete with each other-collectively negotiated these pricing terms on behalf of all rightsholders. That some individual authors or publishers might opt out of those terms does not make them any less the product of collective action by competitors." ${ }^{\circ 0}$ But this argument has zero application to commercially available books, because 
the settlement negotiated by the class representatives rejects those pricing terms on behalf of rightsholders of those books, unless the rightsholders individually decide otherwise. It is hard to see how an agreement not to horizontally agree on something can amount to a horizontal agreement.

Second, for those rightsholders who do choose to accept the Google-set price, the settlement requires Google to set prices using an algorithm that is designed to mimic competitive rather than cartel pricing. The settlement provides:

The Pricing Algorithm shall base the Settlement Controlled Price of a Book, on an individual Book by Book basis, upon aggregate data collected with respect to Books that are similar to such Book and will be designed to operate in a manner that simulates how an individual Book would be priced by a Rightsholder of that Book acting in a manner to optimize revenues in respect of such Book in a competitive market, that is, assuming no change in the price of any other Book. ${ }^{61}$

This provision does not authorize Google to use an algorithm that sets a schedule of cartel prices for all books at the same time that would maximize revenue for all rightsholders collectively. Instead, it explicitly requires Google to mimic the competitive pricing that rightsholders would use by setting the profit-maximizing price for each book separately, without taking into account any effect on prices for other books. This provision thus does not allow Google to raise prices for multiple books simultaneously to levels that, while they would increase group revenue, would not maximize an individual rightsholder's revenue as much as setting the price for its individual book a little lower to undercut the cartel price. Although I think this was also the best interpretation of the original provision, that interpretation required a close reading of the text and possible resort to the canon favoring competitive interpretations (Elhauge 2009c, 25-27). So it was useful that the amended settlement added language to remove any ambiguity.

To see how this provision works, imagine the following case. Suppose there are two books that are partial substitutes but have enough distinctive demand so that with competitive pricing they would each sell at $\$ 5$ rather than at the marginal cost of $\$ 0$, and that if they entered into a cartel the joint profit-maximizing price would be $\$ 10$ for each book. This provision would

61 Amended Settlement $\$ 4.2$ (c)(ii)(2). See also id. $\$ 4.2$ (b)(i)(2) (algorithm must be designed "to find the optimal price for each such Book order to maximize revenues for the Rightsholder for such Book and without regard to changes to the price of any other Book"). 
be violated if Google set a price of $\$ 10$ for each book, because in setting the price for each book separately, each rightsholder would earn more revenue if it undercut that $\$ 10$ price slightly to take sales away from the other book. The same would be true for any price Google might set between $\$ 5$ and $\$ 10$. Thus no price above $\$ 5$ would maximize revenue for each rightsholder when separately setting the price for its book without regard to any effect on the price of the other book.

Indeed, the settlement algorithm not only precludes cartel pricing, it even precludes any form of oligopolistic pricing in any book submarkets, because such oligopolistic coordination does require considering the effects that a price change might have on rival prices. The settlement algorithm thus, if anything, results in more competitive pricing than if individual rightsholders priced the books themselves, because nothing would prevent an individual rightsholder from considering the effects on rival prices and implicitly coordinating if that were possible. ${ }^{62}$

Third, if Google tried to misuse its pricing ability to set book prices at supracompetitive levels, each rightsholder would undercut the price in order to increase sales of its book. Suppose that in the above hypothetical Google did try to set prices at $\$ 10$ per book. Then each rightsholder would have incentives to specify a slightly lower price because that would increase its profits, and the settlement explicitly allows it to do so. The other rightsholders in turn would have incentives to undercut that price, until the prices spiraled down to the competitive level of $\$ 5$. They could do so without giving up Google display or distribution by simply directing Google to charge a lower price. They could also do so by charging a lower price through a Google rival, and wouldn't even have to give up having their book sold or displayed on Google unless they wanted to do so.

The prospect of losing rightsholders to rivals would be particularly costly to Google because Google would lose the $37 \%$ profit on books sales, as well as lose market share to Google rivals. Thus Google would have powerful incentives not to even attempt any price less attractive than the prices charged for commercially available books at other retailers, which includes not only printed books but digital books at rivals such as Amazon Kindle, Sony Reader and Project Gutenberg. Those rival retailers would generally determine prices in a but-for world where Google (which without this settlement currently has a $0 \%$ market share in books) was not a serious seller 
of digital books. ${ }^{63}$ Google's prices for commercially available books thus could generally be no higher than the but-for prices that would be available without the settlement. Indeed, because competition between Google and those rivals should lower rival prices, rival pricing should constrain Google to charge less than but-for prices. Google's lack of incentives to attempt to set supracompetitive prices are even stronger when one recognizes that Google derives $97 \%$ of its revenue from advertising, and thus would not want to sacrifice website traffic by charging high book prices. ${ }^{64}$

In fact, the settlement is even more procompetitive, because it assures consumers of competitive pricing for books sold through the new Google platform by allowing rightsholders to set their own prices on that platform and by requiring Google to set competitive prices. Thus, these provisions not only provide clear procompetitive benefits from the but-for world, but even provide consumers with the benefits of full book competition within the new Google option being added to that but-for world.

Fourth, no anticompetitive effect can flow from any rightsholders' vertical agreements to the 63 percent royalty split that Google offers under the settlement. This royalty split cannot affect consumer pricing because it does not alter the incentives or algorithm for setting retail prices, but instead alters only the distribution of any resulting revenue. Each rightsholder thus has incentives to set a price for its book that, given competition with other books, maximizes the revenue for that individual book, whether it gets $63 \%$ or any other share of that revenue, and the settlement algorithm requires Google to set prices in the same way. Thus, even if (contrary to fact) the settlement did fix the royalty split, it would not "operate as a price floor," as the initial DOJ brief incorrectly asserted, because the royalty split would neither alter nor set any floor on competitively-set

63 Even if we assume printed and digital books will prove to be in separate markets, which will not be clear until we learn more about the extent to which buyers will regard them as reasonably interchangeable, Google is unlikely to gain a large market share in digital books even with the settlement. The reason is that, given that the settlement by default gives Google no rights to distribute commercially available books and that those books generally are distributed by existing publishers, Google will primarily be selling books that are commercially unavailable because of limited consumer demand and that currently constitute less than $3 \%$ of all books sales. See infra at _.. Further, unless new revenue models are approved, Google's digital books will be readable only online, see Amended Settlement $\$ \$ 1.35,1.77,4.7$, and thus may be less attractive than digital books through Kindle or Sony. There is thus little reason to think Google will gain a dominant market share or market power in any digital book market.

64 Google Inc. Form 10-K at 42 (February 13, 2009). 
consumer prices, and 63 percent of a competitively-set price with no floor cannot be a price floor. ${ }^{65}$

Moreover, the settlement in fact does not fix the royalty split, but merely provides a default royalty that either party can reject and that cannot prevail if it does not match an efficient distribution markup. Imagine that Google's $37 \%$ share turns out to too high a markup for its distribution efforts. Then any rightsholder could simply decline to sell its book through Google (without even giving up Google display promotion) and instead sell its book at a Google rival that offers a lower distribution markup, which rightsholders would have every incentive to do if the distribution markup were excessive. Or the rightsholder could threaten to pull its book from Google and bargain with Google to sell the book through Google at a more attractive markup.

Now imagine instead that the $37 \%$ Google share turns out to be inefficiently low. Then Google would have every incentive to drop books unless they would agree to a lower royalty rate. The initial DOJ brief seemed to assume the settlement set a $63 \%$ floor on the royalty share that prohibited Google from demanding a higher distribution markup to carry books. ${ }^{66}$ Although this seems to me a misreading of the original settlement given Google's right to drop books for "non-editorial reasons," the amended settlement removes any doubt that Google can do so for commercially available books. ${ }^{67}$ Thus, if this were the basis for the DOJ's objection, then that basis no longer applies.

Further, if a 37 percent distribution markup were inefficiently low, then that means it would fail to induce an efficient level of distribution effort, and thus rightsholders would also have incentives to raise it. Just like a manufacturer in any vertical distributional restraint, rightsholders would want to increase the downstream share of profits in order to induce an efficient level of distribution effort, and should agree to pay a higher share to Google or its rivals in order to induce or get commitments for more distribution effort. ${ }^{6}$ Settlement critics miss this point when they assert that no rightsholder would ever have incentives to sell through a rival at a lower royalty

65 Initial DOJ Brief at 19.

66 Initial DOJ Brief at 19-20.

67 Supra note 55.

68 Leegin Creative Leather Products, Inc. v. PSKS, Inc., 551 U.S. 877, 896 (2007) ("A manufacturer has no incentive to overcompensate retailers with unjustified margins.... As a general matter, therefore, a single manufacturer will desire to set minimum resale prices only if the increase in demand resulting from enhanced service ... will more than offset a negative impact on demand of a higher retail price.”'); Elhauge 2008b, 441-442. 
rate. ${ }^{69}$ Rightsholders would have incentives to pay more for distribution services whenever that would get them more efficient distribution, thus increasing their book sales enough to offset the higher distribution fee.

In any event, to the extent rightsholders would not pay more than 37 percent for distribution because that is what Google offers under the settlement, this does not mean the rightsholders have horizontally agreed to pay no more than 37 percent. It simply means that the 37 percent distribution fee that Google is individually offering has driven the market price for distribution, much like the price individually offered by any marginal seller might drive the market price for any good or service, leaving independent buyers without any incentive to pay more than the market price. Offering a low price for distribution or anything else is not predatory as long as that price is above cost, ${ }^{70}$ and no one claims that 37 percent results in below-cost pricing for Google's distribution services. Nor would the answer be any different if we instead view Google as buying books and reselling them: the price Google is individually willing to pay for book licenses might drive their market price, but paying an excessive price for book licenses would not be predatory unless it resulted in below-cost pricing in the downstream book market, which again no one claims here. ${ }^{71}$ Indeed, it would be implausible to claim below-cost pricing for either distribution or books given the low incremental cost of distributing digital books and the fact that rightsholder incentives and the settlement algorithm require setting downstream book prices that maximize individual book revenue. However one categorizes the transaction, Google would have no incentive to accept a lower distribution fee or pay a higher royalty than it could have accepted/paid through separate negotiations with rightsholders, and if Google is undercharging/ overpaying with a $37 / 63 \%$ split, it would be equally able to do so without any settlement by publicly offering that split.

Fifth, the agreements here are less restrictive than the usual set of agreements between authors and an individual publisher. In the typical publishing agreement, unlike here, the authors agree (1) to exclusivity, so that rival publishers cannot distribute the same book, and (2) to have their prices set by a common publisher, who is under no obligation to set prices to mimic competition among its book offerings and faces no constraint from authors

69 Initial DOJ Brief at 19-20; Picker 2009c, 408.

70 Brooke Group Ltd. (Liggett) v. Brown \& Williamson Tobacco Corp., 509 U.S. 209 (1993).

71 Weyerhaeuser Co. v. Ross-Simmons Hardwood Lumber Co., Inc, 127 S.Ct. 1069 (2007). 
free to set their own book prices. For such standard publishing contracts, the fact that many authors may agree to the prices and royalty rates offered by the publisher, perhaps in a standard form contract sent to all authors, is deemed neither horizontal nor otherwise problematic. Given that such publishing contracts are more restrictive of competition than the prospective agreements that would result from the settlement, the latter should raise no concern.

\subsection{In-Copyright Books That Are Commercially Unavailable}

Clarifying Rights. Just as for commercially available books, the settlement provides a process for making decisions when it is unclear whether the author or publisher has digital rights over commercially unavailable books. In addition, as Part II showed, the settlement clarifies who has any rights to commercially unavailable books by resolving reversion issues, by funding a Registry to identify rightsholders, by giving rightsholders incentives to come forward, and by making this information available in a public database. Such clarification has no anticompetitive downside, but several procompetitive effects. It procompetitively makes it easier for Google and its rivals to license these books for digital or non-digital sale. (It also decreases the transaction costs of obtaining licenses for a myriad of other purposes, like making a movie or derivative work based on a book.) Without the settlement, unclaimed books would likely go unutilized because, compared to the small rewards from publication, the costs of identifying rightsholders are too high and the risk of penalties for violating copyright law by not getting a license are too great (U.S. Copyright Office 2006, 1). The settlement can thus only increase the output of commercially unavailable books, especially since by definition commercially unavailable books are books for which there would be no new output absent the settlement.

Allowing Book Searches. The settlement allows a digitization of commercially unavailable books that makes them searchable and easier for readers to find, unless the rightsholder removes the book from the database. The terms for doing so are the same as the terms for commercially available books, but the effects are even more procompetitive because commercially unavailable books are by definition currently not advertised and thus difficult to find. Making these commercially unavailable books searchable on Google vastly increases the ability of potential readers to identify and locate the books they want, dramatically increasing the output of these books.

Allowing Display and Nonexclusive Sale Through Google. The settlement terms for displaying and selling commercially unavailable books through 
Google are much the same as those for commercially available books with two exceptions: (1) by default commercially unavailable books can be displayed and sold by Google, ${ }^{72}$ and (2) rightsholders who choose to allow Google to offer consumer purchases of commercially unavailable books must also allow Google to include those books in institutional subscriptions. ${ }^{73}$ The other terms described above for commercially available books are all equally applicable to commercially unavailable books. Thus, rightsholders of commercially unavailable books can (1) remove their book from Google display or sale, (2) choose whatever price they want for sale of their book through Google, (3) sell through a Google rival instead of, or in addition to, selling through Google, or (4) bargain with Google for a different royalty than the default $63 \%$.

As with commercially available books, these provisions procompetitively add a new valuable promotional vehicle for buyers to identify the books they want and obtain them from Google or other sources. But the effects are even more procompetitive on commercially unavailable books because, for them, these provisions makes books commercially available that, by definition, would otherwise be commercially unavailable. To be sure, there is a used book market for commercially unavailable books. But the used book market is limited, constituting 3\% of regular book sales, only a subset of which are also both commercially unavailable and in-copyright. ${ }^{74}$ It is also hard to find books on the used-book market because there is no common database of used books; the settlement would dramatically increase accessibility by allowing online searches, previews, and purchases of commercially unavailable books. Finally, unlike the settlement, the used book market cannot produce any new copies of these books. The settlement thus clearly and sharply increases new output of commercially unavailable books from a but-for baseline of zero.

72 Amended Settlement $\$ 3.2$ (b) (making all commercially unavailable books “display” by default); \$3.3(a) (“Google may make Display Uses and Non-Display Uses of all Display Books”); $\$ 1.52$ ("display uses” includes “access uses”); $\$ 1.1$ (“access uses” means “Institutional Subscriptions, Consumer Purchase and the Public Access Service”).

73 Amended Settlement $\$ 3.5(\mathrm{~b})(\mathrm{iii})$.

74 Total non-textbook sales were $\$ 21$ billion in 2004, of which used book sales represented $\$ 600$ million, or three percent. See Book Industry Study Group 2006. For textbooks, used book sales made up 30 percent of sales, or $\$ 1.6$ billion out of $\$ 5.3$ billion, but given the need to update textbooks with developing academic knowledge, these probably are not usually commercially unavailable books, but rather are used copies of commercially available books that the professor has assigned for a class and are resold by students from prior classes. 
As with commercially available books, settlement critics have argued that anticompetitive cartel pricing is created by the provisions allowing Google to set book prices (if the rightsholder declines to do so) and setting a default royalty (if the parties do not renegotiate). ${ }^{75}$ To consider this argument, it is convenient to separate the discussion of claimed and unclaimed books.

Currently Claimed Books. For commercially unavailable books with currently known rightsholders, the critics' argument fails for all the reasons noted above for commercially available books. It fails for the same reasons that: (1) there is no horizontal agreement but instead a series of vertical agreements by some individual rightsholders to accept the standard settlement pricing and royalties (here by declining to reject them); (2) the settlement pricing algorithm actually mimics competitive pricing; (3) any effort to set supracompetitive pricing would be undercut by rightsholders setting a lower price through Google or its rivals; (4) the default royalty split cannot affect prices and any inefficient royalty split could not be maintained; and (5) the arrangements are no more horizontal and less restrictive than a series of agreements with a publisher that uses a standard form contract that applies unless the author opts out of it.

But here the critique also fails for a powerful additional reason: new output of commercially unavailable books would remain zero but for the settlement because commercially unavailable books are, by definition, books with zero output outside the settlement. This fact means that the price for new output of commercially unavailable books would exceed anyone's willingness to pay given the thin demand and relevant economies of scale in publishing. Even if one thought the settlement would allow monopoly pricing for commercially unavailable books, such pricing would necessarily be at levels that many are willing to pay and thus would be below this but-for price and increase output from zero to something. These are unambiguous procompetitive effects from the proper but-for baseline.

This same factor also undermines the argument that default terms on prices and royalties amount to horizontal price-fixing among rightsholders. The Initial DOJ Brief reasoned otherwise because "Class representativeswho compete with each other-collectively negotiated these pricing terms on behalf of all rightsholders." ${ }^{76}$ But commercially unavailable books by

75 Initial DOJ Brief at 17-22; Amazon Initial Brief at 1, 18-24, 30; Yahoo Initial Brief at 22-23; Fraser 2009, 15-17; Picker 2009c, 383, 385, 398, 408.

76 Initial DOJ Brief at 18. 
definition do not "compete with each other." They don't compete with anyone because they are not offered for sale at all. Given that they are not-and would not be-horizontal competitors, any agreement among them cannot be a horizontal agreement. Restraining competition among persons who would offer no product absent the restraint does not restrain any horizontal competition - it creates some horizontal competition that otherwise would not exist, not only among those persons, but between them and others.

The Initial DOJ Brief seemed to doubt that the settlement was necessary to offer commercially unavailable books, pointing out that many digital books were already available for purchase, including "growing numbers of out-of-print books." ${ }^{\prime 7}$ But, as noted above, this ignores the fact that commercially unavailable books are, by definition, books that will not be available for purchasing from another source, and thus any out-of-print books that in the future are available for digital purchase from another source would not, during the time of any such availability, be deemed commercially unavailable by the settlement, and thus would not be covered by any default license. Instead, such books would become commercially available, and the settlement would by default have their rightsholders reject any settlement terms on pricing and royalties. The settlement makes these books saleable only because the default licenses lower transaction costs and allow them to offered as part of near-universal libraries. The Initial DOJ Brief asserted that such default licenses did not seem reasonably necessary to offer these commercially unavailable books. ${ }^{78}$ But if default licenses are not necessary to offer these books, then rivals will offer these books without such default licenses, and they will no longer be commercially unavailable and covered by the settlement's default license.

At worst, one might say that this sort of agreement had mixed horizontalvertical features. If so, then the most relevant precedent are cases involving dual distribution agreements, which make clear that even though such agreements have horizontal aspects, their classification should not turn on arid formalisms, but rather on a substantive assessment about whether the agreement is likely to have pernicious anticompetitive effects with no redeeming procompetitive virtue. ${ }^{79}$ Given that here there can be

77 Initial DOJ Brief at 20 .

78 Initial DOJ Brief at 22.

79 Copy-Data Systems v. Toshiba America, 663 F.2d 405 (2d Cir. 1981); Abadir \& Co. v. First Mississippi Corp., 651 F.2d 422 (5th Cir. 1981). 
no anticompetitive effect on books that otherwise would be commercially unavailable, and powerful procompetitive effects to making them available, the settlement provisions on pricing claimed commercially unavailable books should clearly be characterized as vertical.

Indeed, even if the agreement were properly classified as involving a horizontal price-fixing agreement, $B M I$ makes clear that, if ancillary to a productive joint venture, such an agreement must be assessed under the rule of reason. ${ }^{80}$ Here, the default terms on prices and royalties are clearly ancillary to a productive joint venture in offering for sale books that, without such default licenses, would not be commercially available at all, let alone available in a near-universal library that makes the collection of books offered more valuable. As shown in Part IV, the procompetitive effects of this settlement are quite similar to those in BMI: in both cases, the agreements created the new product of a blanket license in copyrighted works (here books, there songs) and lowered transaction costs to licensing those songs without taking away any but-for option of individual transactions outside intermediary. That was sufficient to sustain the BMI agreement under the rule of reason. But the settlement here is even more procompetitive than the one in BMI because the settlement here also allows: (1) individual sales by the intermediary, which was the remedy sought by the BMI plaintiff, (2) rightsholders to set their own price for sales through the intermediary, a competitive right not even dreamed of in BMI, and (3) rightsholders who sell through one intermediary to sell the same work through rival intermediaries, something that was affirmatively prohibited in the agreements sustained in BMI.

Currently Unclaimed Books. For currently unclaimed books, we can further divide them into two subgroups: those who would become claimed after the settlement and those that would not. Let's start with the former group. Because the settlement funds a Registry to identify rightsholders and gives them incentives to self-identify, many of these currently unclaimed books will become claimed. For their books, the procompetitive effects will include all those noted above for claimed books. In addition, the settlement will have the procompetitive effect of making these books available for licensing by Google rivals that might wish to either take advantage of low digital distribution costs to offer their own digital versions

80 BMI v. CBS, 441 U.S. 1 (1979). See generally Elhauge 2008b, 50-51, 141 explaining when horizontal price-fixing is covered by the rule of reason. 
or respond to a demonstration of surprising demand for some of these books by republishing a printed version. This will reduce the effective royalty rate for licensing these currently unclaimed books from infinity, and will increase the licensing of these books from zero to something.

It seems likely that at least $80 \%$ of currently unknown rightsholders could be located by the Registry because a recent study by the Carnegie Mellon University Library indicates that approximately 80 percent of rightsholders can be located and induced to respond using letters alone (Covey 2005, 13). The actual percentage is likely higher because the Registry could engage in more extensive efforts, and because the settlement will create an easy and salient online site for rightsholders to identify themselves and pay royalties that give them strong incentives to do so. Thus, for currently unclaimed books, the effects will be unambiguously procompetitive for at least 80 percent of them and probably for far more.

For the (less than 20 percent of) currently unclaimed books that would remain unclaimed despite Registry searches and incentives for self-identification, the results are also unambiguously procompetitive. These books are effectively not only unclaimed but unclaimable given the relevant rewards and costs for making a claim. In the but-for world, such unclaimable books would be both commercially unavailable and unlicensable. Their output would be zero, and their effective royalty rate would be infinity. Further, without a class action settlement, this would be true in any conceivable but-for world because if these rightsholders cannot be identified with this settlement, they are almost certainly unidentifiable through any feasible means. The settlement thus clearly increases the output of these unclaimable books from zero and reduces their effective price and royalty rate from infinity.

The Initial DOJ Brief argued that a default license covering prices and royalties was not reasonably necessary to sell commercially unavailable books. ${ }^{81}$ But the DOJ offered no explanation of how, without some default terms on prices and royalties, one could ever offer unclaimed books, given that by definition there is no known rightsholder to negotiate with on them. Indeed, the DOJ's claim that such a default license was not reasonably necessary was inconsistent with the DOJ's other claim that rivals could never offer unclaimed books without such a default license. ${ }^{82}$

81 Initial DOJ Brief at 20, 22.

82 Initial DOJ Brief at 23. 
To be sure, given that the rightsholders of unclaimable books would remain unknown, their rightsholders could not individually set prices through Google or decide to license rivals to undercut any monopoly pricing through Google. However, when setting prices for unclaimed books, Google must use the same competition-mimicking algorithm used for claimed books. ${ }^{83}$ Pricing for unclaimed books will thus be constrained by the direct terms of the competition-mimicking algorithm. In addition, the fact that the same algorithm must be used for both claimed and unclaimed books means that any attempt to misuse the algorithm to set supracompetitive prices for unclaimed books will be constrained by all the market forces (described above) that would prevent supracompetitive algorithm pricing for claimed books, including the fact that rightsholders of claimed books would undercut any supracompetitive algorithm prices. Given that over 97 percent of the revenue comes from commercially available books (which are all claimed), ${ }^{84}$ and at least 80 percent of currently unclaimed books will likely become claimed, ${ }^{85}$ this means that over 99 percent of all book revenue will come from claimed books, even without adjusting for the share of commercially unavailable books that are already claimed. Google could not plausibly be tempted to use supracompetitive prices that lose it market share in more than 99 percent of the market in order to increase profits in less than 1 percent of the market.

Several other factors would also constrain Google from trying to misuse the competitive-pricing algorithm to set supracompetitive prices for unclaimed books. First, unclaimed books compete with claimed books. If claimed books, which form over 99 percent of the market, are being priced competitively, it is unlikely that supracompetitive prices can be charged for unclaimed books, especially because the main reason the latter will be unclaimed is that there is little demand for them.

Second, Google makes 97 percent of its revenue from advertising. ${ }^{86}$ Supracompetitive pricing on unclaimed books that reduced traffic to its site would thus likely lose Google more advertising revenue than it could gain in sales.

Third, if Google tried to set supracompetitive prices on unclaimed books, that would strongly increase the incentives of their rightsholders to identify

\footnotetext{
83 Amended Settlement $\$ 4.2(\mathrm{~b})$.

84 Supra at p. 43.

85 Supra at p. 47.

86 Supra at 39 and n. 34.
} 
themselves to get their royalties. After all, rightsholders are typically unidentified because they are difficult to locate, not because they are unaware that they hold copyrights. ${ }^{87}$ Thus, given the negligible costs of registering, one would expect them to do so if they could reap supracompetitive profits. If 63 percent of these profits are insufficient to induce this effort by the rightsholders, those profits are likely negligible, and 37 percent of such negligible profits would certainly be insufficient to induce Google to violate the algorithm to set excessive pricing on unclaimed books, especially since excessive algorithm pricing risks not only the other 99 percent of the book market that is claimed, but also the search advertising revenue that provides 97 percent of Google's profits.

Fourth, to the extent that attempted supracompetitive pricing did not induce unknown rightsholders to identify themselves, it might well induce some rivals to offer their books without a license, which would deter Google from attempting the supracompetitive pricing in the first place. ${ }^{88}$ Normally, publishers are reluctant to sell any book without a copyright license, but the fact that these rightsholders have not bothered to register to earn supracompetitive profits suggests that they are unlikely to file copyright infringement cases either, making the odds of copyright penalties low. The supracompetitive pricing would also increase the benefits of publishing without a license. Google would be particularly reluctant to induce this sort of rival competition because the rival could easily undercut Google given that the rival would not be paying any royalties: the rival could charge 37 percent of the price that Google charges and still earn the same profit per book sale. To be sure, if a rival sold unclaimed books without a license, it might invite a class action lawsuit on behalf of unregistered rightsholders. But if so, that brings us to the next constraint.

87 United States Copyright Office, Report on Orphan Works 22-34 (2006) (listing as reasons for orphan works difficulties in identifying and locating the rightsholders, not the unawareness of the rightsholders that they have copyrights).

88 Acknowledging this factor does not imply any normative approval of such copying without a license. It is simply a positive observation about a factor that would constrain any feared supracompetitive pricing, and to the extent the factor holds, the unlicensed copying would never occur because the mere threat of it would induce Google to lower prices enough to prevent it from occurring. Nor is the normative issue so clearcut. The situation involves rightsholders who by definition (1) stopped offering their books commercially, (2) cannot be identified despite diligent search, and (3) have not come forward despite the public offering of their books on the Internet. Although the copyright interests of such rightsholders are not technically abandoned property, they come close enough that one might argue they deserve similar normative treatment. In any event, even if one puts aside this factor out of distaste, all the other factors would still clearly suffice to constrain any supracompetitive pricing. It would also remain the case that the settlement actually does not constrain any form of competition that would exist without the settlement and that it in any event requires competitive pricing within the settlement as well. 
Fifth, supracompetitive pricing for unclaimed books would to some extent be constrained by the ability of Google rivals to obtain similar default licensing rights for these books through the same class action mechanism. Settlement critics argue that provoking such a second class action lawsuit would be prohibitively risky. ${ }^{89}$ But the risks would seem lower than those incurred by Google, even if the same digitization were done, because at that time there was no precedent for such a settlement. The rival could further lower its risks by limiting its digitization to unclaimed books. Given that the affected rightsholders would be unknown, it would seem difficult to find named plaintiffs for such a class and also difficult to get a court to award monetary recovery when there is no way to identify who would receive the damages. If the rival's digitization did not provoke a second class action, then the rival would effectively get free rights to the same books that Google pays 63 percent to sell. This possible payoff may well be worth any financial risk, especially because if the rival digitization did provoke a second class action, then the rival could settle on terms that gave it the same sort of default license over unclaimed books that Google obtained.

Settlement critics argue that the plaintiffs in a second class action would be unlikely to give the rival as good a settlement as Google got (Samuelson 2009a; Picker 2009c, 405). But their argument seems to presuppose that the second class action would be controlled by the same group that brought the first. This is not clear. A rival class action might well involve different groups and the creation of a second Registry or Fiduciary, which would have incentives to settle on terms that licensed the rival at prices that undercut Google because then the rival would gain market share and pay more into the second Registry or Fiduciary.

Even if rightsholders in the rival's class action were represented by the first Registry and Fiduciary, they would have incentives to undercut any supracompetitive retail pricing in a settlement licensing the rival, because doing so would minimize the distribution markup. To see why, suppose Google were on average charging a supracompetitive retail price of $\$ 10$ for unclaimed books when the competitive price would be $\$ 5$. Then rightsholders would be receiving $\$ 6.30$ per book sale from Google, and thus a Fiduciary representing them should be happy to charge $\$ 6.30$ per book to a rival that charged consumers $\$ 9$ instead. The Fiduciary would have incentives to do 
so because at a lower downstream price, more books would be sold and thus the rightsholders would receive $\$ 6.30$ per book on more book sales.

Indeed, as noted above, the settlement authorizes the Registry and Fiduciary to license rivals "the extent permitted by law." ${ }^{90}$ If this gives them authority to grant default licenses to rivals, they would have similar incentives to license Google rivals to reduce any supracompetitive pricing. The ability to license rivals will thus constrain the distribution markup to the extent 37 percent is too high a distribution fee. It will also constrain book pricing because, given that Google is paid a percentage of book revenue, any supracompetitive book price would result in a supracompetitive distribution markup that the Fiduciary would have incentives to undercut, just like any upstream manufacturer facing a supracompetitive distribution markup. Moreover, because a rival who undercuts Google's prices would lower Google's market share, Google would have strong incentives never to engage in supracompetitive pricing that induces the Fiduciary to license rivals.

Sixth, even if (contrary to fact) the settlement did allow monopoly pricing over unclaimable books, the settlement would still be procompetitive because one market option is better than none and monopoly pricing is better for consumer welfare than no market at all. The but-for alternative for unclaimable books is no licensing at all, which produces the anticompetitive output of zero and effective prices and royalty rates of infinity on new output. Even monopoly pricing would necessarily increase output and lower effective prices and royalty rates from that but-for baseline. One must also keep in mind that unclaimable books comprise a very small share of the overall market and will continue to shrink if the settlement is approved.

\subsection{Institutional Subscriptions to View All Google Books}

The settlement also procompetitively creates a brand-new product-the institutional subscription-under which universities, schools, corporations, governments, and other institutions can buy blanket licenses to access all commercially unavailable books that are available for consumer purchase through Google, as well as any commercially available books the relevant rightsholders choose to include in the institutional subscription. ${ }^{91}$

90 Supra at pp. 5, 11-12 and 24.

91 Amended Settlement $\$ 4.1(\mathrm{a})(\mathrm{v})$ (institutional subscription includes all books available for such subscriptions); \$3.5(b)(iii) (commercially unavailable books available for consumer purchase must also be available for institutional subscription, but commercially available books need not be). 
Rightsholders can withdraw their books from the institutional subscription if they wish and, as always, remain free to directly license or sell their books to anyone who prefers that option to the institutional subscription. In addition to selling institutional subscriptions, Google must provide free access to them at one or more terminals at each college and public library. ${ }^{92}$

Creating this new product is a huge procompetitive benefit that could not exist absent the settlement. Nondigital technology simply does not permit a book supplier to sell blanket access to millions of volumes. Nor would any vaguely comparable existing product — such as, hypothetically, paid access to a university library - allow large numbers of users to simultaneously search through or annotate these products with comparable ease. Such institutional subscriptions promise to be an enormous boon to researchers, allowing them to delve into books freely before knowing how valuable the books may be to their research and without being deterred by any marginal monetary or transaction costs.

Settlement critics object that Google and the Registry will have a monopoly over such institutional subscriptions, and thus will be able to charge a monopoly price. But this concern is misplaced for several reasons. First, the settlement requires that institutional subscriptions be priced to achieve two objectives:

(1) the realization of revenue at market rates for each Book and license on behalf of Rightsholders and (2) the realization of broad access to the Books by the public, including institutions of higher education. ${ }^{93}$

The first objective requires that revenue be realized at "market" rates for "each" book, and thus requires that pricing achieve only competitive market returns, just like the competitive-pricing algorithm does for individual consumer purchases. The second objective reinforces this goal by requiring that pricing be low enough to realize "broad access" by the public. If the price were raised to a high enough level that a substantial number of institutions decided to refrain from subscribing, Google will be obligated to lower the price to achieve broad access. In essence, this requirement bars any monopoly or supracompetitive pricing that would create allocative inefficiency

92 The Amended Settlement itself says Google "may" provide one terminal per 4,000 students at two-year colleges, one terminal per 10,000 students at four-year colleges, and one terminal per public library or more than one if the Registry so authorizes. Amended Settlement $\$ 4.8(\mathrm{a})$ (i). However, in a separate agreement Google has contractually committed to provide this authorized public access service within two years. See Amendment to Cooperative Agreement (Between Google and the University of Michigan) Attachment A, at \$3(a) (May 19, 2009).

93 Amended Settlement $\$ 4.1(\mathrm{a})(\mathrm{i})$. 
in terms of some significant set of buyers not taking the output. Instead, institutional subscriptions must be priced low enough to produce the sort of broad access that is consistent with the market output that would exist with competitive pricing.

To the extent that this provision were at all ambiguous on these points, if interpreting the provision to allow setting supracompetitive prices would create an antitrust violation, then standard canons of contractual construction would require reading the provision to avoid that illegality. ${ }^{94}$ Indeed, even if interpreting the provision to allow supracompetitive prices were not illegal, then contractual canons would require reading the term to maximize competition and further the public interest. ${ }^{95}$

Some settlement critics argue that the "broad access" requirement would not constrain monopoly pricing because demand for these institutional subscriptions would be "completely inelastic" (Darnton 2009a). But this assertion is implausible. Institutions have many demands on their funds and would not be willing to pay an infinite price for institutional subscriptions, particularly because they can turn to substitutes that include not only current libraries and interlibrary loan, but also the free terminals provided under the settlement and the option of buying individual books through Google. Indeed, libraries today often decline to buy many books, thus confirming that their demand for books is not completely inelastic, and most of the books covered by the institutional subscriptions will likely be books the libraries declined to buy. ${ }^{96}$ In any event, even if the "broad access"

94 Walsh v. Schlecht, 429 U.S. 401, 408 (1977) ("ambiguously worded contracts should not be interpreted to render them illegal and unenforceable where the wording lends itself to a logically acceptable construction that renders them legal and enforceable."); Nat'l Labor Relations Bd. v. Local 32B-32J Serv. Employees Int'l Union, AFL-CIO, 353 F.3d 197, 202 (2d Cir.2003) (same); Restatement (Second) of Contracts $\$ 203(\mathrm{a})$ (1981) (“[A]n interpretation which gives a ... lawful ... meaning to all the terms is preferred to an interpretation which leaves a part ... unlawful ....”).

95 Restatement (Second) of Contracts $\$ 207$ (1981) ("In choosing among the reasonable meanings of a promise or agreement or a term thereof, a meaning that serves the public interest is generally preferred."); Farnsworth 2004, vol. 2, \$7.11, 304 ("if the language is reasonably susceptible to two interpretations and only one favors the public interest, this interpretation will be preferred."); Atlanta Center Ltd. v. Hilton Hotels Corp., 848 F.2d 146, 148 (11th Cir. 1988) (when a contractual term "is susceptible of more than one reasonable interpretation, the preferred interpretation is the one that least restricts competition, thereby posing the least affront to the public policy."); Herrera v. Katz Communications, 532 F. Supp. 2d 644, 647 (S.D.N.Y. 2008) ("a meaning which serves the public interest ... is preferred over a meaning which does not").

96 See Norman Oder 2008, explaining that public libraries face budget constraints; see also Daniel Clancy 2009, noting that institutional subscriptions will provide libraries with access to "million of additional books." 
requirement did not constrain pricing, the requirement that revenue be limited to competitive market returns for each book would.

Some settlement critics also object that (1) the Amended Settlement terms "don't create a mechanism to control any monopoly power" over institutional subscriptions (Picker 2009b, 2), or that the mechanisms that they do create are enforceable only by the Registry, which (critics claim) has no incentive to object to high prices. ${ }^{97}$ But both claims are simply untrue. The Settlement provides that "all disputes between and among Google, Rightsholders, Claimants, the Registry and Participating Libraries arising out of this Settlement Agreement" are subject to arbitration, and it explicitly states that arbitration shall apply to disputes regarding the pricing of institutional subscriptions. ${ }^{98}$ Any individual rightsholder thus clearly has standing to challenge any high institutional subscription price in arbitration, which is likely to be the case for at least one rightsholder because many are ideologically committed to free access and many others would simply have incentives to broaden access to their works if (like most academics with university press books) they care more about being read than about the paltry royalties they are likely to get. Further, while the settlement itself is ambiguous about whether university libraries can bring such a challenge, ${ }^{99}$ subsequent agreements make clear that universities can bring arbitration if Google tries to charge university subscription fees that violate these

97 Darnton 2009a ("Only the registry, acting for the copyright holders, has the power to force a change in the subscription prices charged by Google, and there is no reason to expect the registry to object if the prices are too high").

98 Amended Settlement \$\$ 9.1(a), 9.3(e)(iii).

99 The settlement defines "participating libraries" to mean "Fully Participating Libraries, Cooperating Libraries, Public Domain Libraries and Other Libraries,” Amended Settlement $\$ 1.103$, so all of them have standing to arbitrate if they have a dispute "arising out of this Amended Settlement Agreement." $\$ 9.1(\mathrm{a})$. However, it is not clear whether these libraries have rights arising out of the settlement to enforce $\$ 4.1(\mathrm{a})$ 's requirements for institutional subscription pricing, because the libraries are not parties to the settlement agreement and the settlement provides a list of the provisions for which libraries are third-party beneficiaries that does not include $\$ 4.1(\mathrm{a})$. See $\$ 7.2(\mathrm{f})$. Arguably $\$ 7.2(\mathrm{f})$ excludes by implication library third-party beneficiary status under $\$ 4.1(\mathrm{a})$, although one could instead read $\$ 7.2(\mathrm{f})$ to clarify the provisions for which libraries definitely had this status without resolving which other provisions might also confer that status. See Elhauge 2008a, 189-190, noting that courts sometimes apply the expressio unius canon that listing some applications excludes unlisted applications and other times hold that listed applications can include unlisted ones by analogy, and some reasons supporting the latter. 
requirements. ${ }^{100}$ Universities would have clear strong incentives to bring such challenges to minimize the fees they must pay. Outside of arbitration, the provision limiting subscription pricing might also be enforceable in court by nonuniversity institutions or the general public on the theory that they are intended third-party beneficiaries of that provision. ${ }^{101}$ Such an intent to benefit could be grounded in the fact that the provision explicitly lists the need to provide the "public" with broad access and seems explicitly designed to protect institutions from high subscription fees. ${ }^{102}$ Again, to the extent there was any ambiguity, the settlement must be interpreted to avoid antitrust illegality and favor the public interest.

Second, any attempt to violate this provision and charge excessive institutional subscription fees would be constrained by other forces. To begin with, it would be constrained by Google's own incentives to keep fees low in order to promote its brand and encourage use of its search engine, from which it reaps the advertising revenue that provides 97 percent of its profits. In addition, high subscription prices would to be constrained by competition from free library terminals, the ability to purchase books through Google or other sources, and the fact that rightsholders retain the right to directly license or sell their books whether or not those books are included in the institutional subscriptions. The last constraint is particularly significant legally because, as we shall see, precisely that sort of constraint was deemed sufficient to eliminate anticompetitive effects in BMI.

High subscription fees would also be constrained by the prospect of rivals offering their own institutional subscriptions at lower rates. Rightsholders will be just as able as Google to obtain licenses for commercially available

100 Amendment to Cooperative Agreement (Between Google and the University of Michigan) Attachment A (May 19, 2009), at $\$ 1(d)$ (defining an "interested institution" to include any fully participating or cooperating library); \$3.c (allowing any “interested institution” to challenge university subscription rates).

101 Restatement (Second) of Contracts $\$ 302$ (1981); Farnsworth 1990, $\$ 10.3$.

102 Cutting the other way is the fact that the the settlement defines third-party beneficiary rights for libraries but not other institutions, Amended Settlement $\$ 7.2(\mathrm{f})$, which one could say excludes by implication any intent to benefit other institutions. However, the provision could equally be read to simply clarify the extent to which libraries are definitely third-party beneficiaries without resolving whether and when other institutions might also be intended beneficiaries. See supra note 99 (noting mixed application of the expressio unius canon). Supporting the latter interpretation is the Restatement, which provides "It is not essential to the creation of a right in an intended beneficiary that he be identified when a contract containing the promise is made." Restatement (Second) of Contracts $\$ 308$ (1981). Here the institutions and public were in fact identified, though their third-party beneficiary status was not explicitly identified. 
books and journals, which are what institutions mainly buy. ${ }^{103}$ Rivals who wanted to offer an institutional subscription of comparable scope could also seek licenses for any commercially unavailable books, which (as described above) the settlement makes easier in several ways. (A) The settlement creates a public database that makes it easy for rivals to make a mass offer to all registered rightsholders to license their books. (B) The settlement allows the Registry to collect licenses from multiple registered rightsholders and license them in aggregate to rivals, which the Registry and rightsholders have incentives to do. (C) The settlement might be read to provide the Registry and Fiduciary with authority to license books to rivals absent rightsholder objection, in which case they could grant rivals precisely the same default rights over all commercially unavailable books that Google has, and would have incentives to do so. (D) The settlement provides a roadmap as to how rivals could engage in digitization to provoke a second class action and obtain similar default licenses for all commercially unavailable books. If the second class action were controlled by the same forces that control the Registry, they would have incentives to license the rival. If it were not, then the second set of class action plaintiffs would have clear incentives to license a rival and undercut the Google subscription price.

In short, if methods $(C)$ and $(D)$ prove feasible, a Google rival could obtain default rights over all commercially unavailable books - even if unclaimedand thus could offer precisely the same institutional subscription as Google. If methods $(C)$ and $(D)$ prove unfeasible, then the rival could not obtain licenses over unclaimed books, but unclaimed books currently provide only a fraction of commercially unavailable book revenue and will provide an even smaller fraction once the settlement lowers the number of unclaimed books. Thus, even if $(C)$ and $(D)$ prove unfeasible, the rival institutional subscription could be a close substitute for the Google subscription, and indeed could be more attractive than Google's subscription if the rival offers more commercially available books, lower prices, or additional features.

Third, even if the critics were right both that the settlement gives Google the power to price institutional subscriptions at monopoly levels and that rivals could not possibly offer a similar competing subscription, the settlement would still be procompetitive because having one firm offer a desired product is preferable to having no firm offer it. After all, if rivals cannot offer an 
institutional subscription, and the critics also succeed in making it impossible for Google to offer an institutional subscription by blocking this settlement, then no one will offer a similar institutional subscription. The but-for output of such subscriptions will thus be zero and the but-for price will effectively be infinity. Even monopoly output and pricing would thus expand output and lower effective prices relative to the proper but-for baseline. Indeed, to the extent critics are right that this new product would be so attractive relative to alternative market options that demand for it would be completely inelastic, then that just underscores how harmful to consumer welfare it would be to deny buyers access to such a product by rejecting this settlement.

\subsection{Other Procompetitive Benefits}

The settlement also has several other profound procompetitive effects. First, under the settlement, Google intends to display books in such a way that users unable to read print will be able to access them to the same extent as users without any disability, and Google must provide displays that accommodate their disabilities without charging them a higher price. ${ }^{104}$ For the 15-30 million Americans who are print-disabled, this will dramatically expand their access to written knowledge, perhaps more than anything since the invention of Braille. ${ }^{105}$ In the less evocative language of antitrust economics, this is an enormous increase in market output and consumer welfare for 5-10 percent of Americans.

Second, Google will designate two research centers to house the digital copies of all books that it has scanned, and qualified researchers will be given free access to these files in order to conduct "non-consumptive" research, which is defined as research unrelated to the intellectual content of the works, such as developing search algorithms or conducting linguistic

104 Under Amended Settlement $\$ 7.2(\mathrm{~g})$, Google “intends" to display books in a way that satisfies the $\$ 3.3(\mathrm{~d})$ goal of providing the print-disabled a similar experience to the nondisabled and "must ... use commercially reasonable efforts to enable an Accommodated Service," which includes displaying books "in the form of electronic text used in conjunction with screen enlargement, voice output, and refreshable Braille displays . . . at no greater charge than the charge to view Books in a similar manner to users ... without a Print Disability."

105 See Reading Rights Coalition 2010, estimating that there are about 15 million print-disabled people in the United States; Council on Access to Information for Print-Disabled Canadians 2000 , estimating that 10 percent of Canadians are print-disabled, which would imply 30 million are in the United States. 
analyses. ${ }^{106}$ The creation of this research corpus will enable researchers in a variety of disciplines to conduct technical analyses across the universal library of books that would have been exponentially more difficult, if not entirely impossible, absent the settlement. This, too, is in effect a new product, and one that can lay the groundwork for new technologies in full-text searching, automated translation, and other areas of programming.

Third, the settlement will provide a vast increase in the availability of human knowledge that is desirable for its own sake and promises to improve research to further advance knowledge. The net effect of the increased accessibility of each category of book-the uniformly positive effects, that is, which the settlement will have on consumers' ability to locate and read books of all sorts - will be a quantitative and qualitative expansion of the information available online. Readers will be able to read many commercially unavailable books that are currently either severely limited in their distribution or wholly unavailable. Further, researchers will be able to perform online research to find and analyze both commercially available and unavailable books that today are inaccessible online with the exception of a small portion of public domain works. This current online inaccessibility today means that relatively ephemeral information is privileged over longterm, enduring knowledge. The settlement thus would not only increase the sheer amount of information online, by adding billions of pages of digitized books, but also ameliorate this distortion in the kinds of information available online. Research would correspondingly improve, and every industry performing online research will enjoy efficiency gains. This effect is augmented by Google's agreement to provide free access to all books in its database at one or more terminals in libraries and colleges, which would allow large numbers of interested users to access the information at no cost.

\section{THE SETTLEMENT COMPARES FAVORABLY TO THE BLANKET COPYRIGHT LICENSES APPROVED IN BMI}

As Part 3 explained, the settlement does not involve a horizontal price-fixing agreement because commercially unavailable books are not horizontal

106 Amended Settlement $\$ 1.132$ (“'Research Corpus’ means a set of all Digital Copies of Books made in connection with the Google Library Project"); \$7.2(d)(ii) ("The Research Corpus may be hosted at up to two Host Sites at any given time"); $\$ 7.2(\mathrm{~d})(\mathrm{i})$ ("The Research Corpus may be created and used for Non-Consumptive Research"); $\$ 1.93$ ("Categories of Non-Consumptive Research include ... Image analysis and text extraction ... Textual analysis and information extraction ... Linguistic analysis ... Automated Translation ... Indexing and Search”). 
competitors with any book and commercially available books presumptively reject any pricing terms under the settlement. But even if we thought the settlement did involve horizontal price-fixing, the precedent closest to this case is $B M I v$. CBS, which involved copyrights to perform songs rather than to reproduce book content. In that case, as here, millions of rightsholders provided copyright licenses to an intermediary, which in turn sold blanket licenses to users that combined all their copyrighted materials. The Supreme Court held that this agreement was not per se illegal because it furthered the procompetitive purposes of (1) lowering the transaction costs of identifying and negotiating with millions of individual rightsholders, and (2) creating a new product (the blanket license) that otherwise would not be possible. ${ }^{107}$ On remand, the Second Circuit held that the agreement survived the rule of reason because it lacked any anticompetitive effect, given that users remained free to directly license the songs from rightsholders. ${ }^{108}$ This logic is all equally applicable to the settlement here. Indeed, the settlement confers these procompetitive benefits and more, and is less restrictive of competition in several respects.

As in $B M I$, the settlement here both (1) lowers the transaction costs of identifying and negotiating with millions of rightsholders; and (2) creates a new product (a blanket license or institutional subscription) that otherwise would not be available. The initial DOJ brief disputed this parallel, arguing that the rightsholders here, unlike in $B M I$, have not shown that they could not sell their books without collective pricing. ${ }^{109}$ But the institutional subscription is a blanket license that by definition cannot be sold without a collective price, the settlement rejected collective pricing for individual sales of commercially available books, and the default pricing for individual sales of commercially unavailable books permits sales of books that by definition would not otherwise be sold (including unclaimed books that could not otherwise even be licensed for sale). Further, whereas in BMI the agreement achieved its procompetitive purposes by simply grouping the rights in one intermediary that licensed those rights together, the settlement here not only accomplishes that feat, but additionally furthers these procompetitive purposes by clarifying rights and digitizing the copyrighted material in a way that makes it far 
easier for users to locate and use the materials they want. Also as in BMI, the settlement here does not bar direct purchases from the rightsholders and thus cannot impede competition among them. But in addition, the settlement here is less restrictive than the BMI arrangement in three other important respects.

First, in BMI the intermediary offered a blanket license but not individual songs. Indeed the whole case was about the intermediary's refusal to sell songs separately, and the remedy sought by the plaintiff was an order directing the intermediary to sell songs individually. ${ }^{110}$ Under the settlement here, Google is already committing to offer books both individually and in a blanket license. The Initial DOJ Brief oddly argues that providing the option of individual sale makes this settlement less procompetitive than $B M I,{ }^{111}$ but it is hard to see how providing an additional market option (without taking away any) could be anticompetitive, especially when it provides the very option that the plaintiff sought as an antitrust remedy in BMI. The initial DOJ position amounts to forcing Google to tie the sale of books in one exclusive license rather than sell them separately, and while some argue that tying should be per se permissible, ${ }^{112}$ I don't know of anyone who contends it should be required. In any event, this DOJ argument presupposes that the terms by which Google sells books are anticompetitive, a premise that was already rebutted in Part 3 and that the DOJ itself may no longer hold now that various settlement amendments have been made. $^{113}$

One settlement critic takes the opposite tack of the DOJ, claiming that under the settlement Google would not extend the sale of individual books to institutions, which he argues is inconsistent with the fact that since 1941 consent decrees have barred the BMI intermediaries from offering only

110441 U.S. at 18.

111 Initial DOJ Brief at 18-19.

112 See generally Elhauge 2009b, discussing and rejecting this claim.

113 The Inital DOJ Brief also distinguished BMI on the ground that here the rightsholders were collectively agreeing on the minimum royalty they would charge Google, see Initial DOJ Brief at19, but this argument was also already rebutted in Part III and the DOJ may no longer holder it now that the Amended Settlement explicitly provides that Google is not bound to pay the default royalty but can drop books whose rightsholders refuse to renegotiate it. 
blanket licenses. ${ }^{114}$ But nothing in the settlement suggests Google could or would discriminate among purchasers of individual books based on whether they belonged to institutions. Google would presumably not allow an institution to purchase a book individually and then share it among all of its members, because that would be tantamount to buying multiple copies for the price of one. But prohibiting that sort of multiple usage would just provide a meaningful distinction between per-book and subscription purchases, and requiring licenses that permitted multiple usage of a single song was not the remedy sought in BMI. It is thus hard to see how the Google settlement could violate the antitrust laws when it not only meets the standards required by $B M I$, but even fulfilled the plaintiff demands that the $B M I$ Court held were beyond antitrust requirements.

Second, in $B M I$ the rightsholders could set their own prices only by going outside the intermediary, which was costly. In contrast, here the settlement explicitly allows rightsholders not only to license directly, but also to set their own prices for sales through the intermediary for all individual book sales. ${ }^{115}$ Thus, here the settlement procompetitively has the intermediary provide a clearinghouse for rightsholder competition that the $B M I$ intermediary declined to provide. It obviously is not possible for individual buyers to set their own prices for a blanket license (like the one in $B M I$ or the institutional subscription here) because the collection of all their rights is what is being sold. However, in BMI, neither the Supreme Court nor the appellate court opinions found this troubling. To be sure, the BMI consent decree allowed a court to review whether blanket license prices were reasonable, as the Initial DOJ Brief stressed in trying to distinguish BMI. ${ }^{116}$ But neither court in BMI relied on that aspect of the consent decree; instead, they relied on the fact that the consent decree preserved the option of buying directly from individual rightsholders. ${ }^{117}$ The appellate court stressed that no anticompetitive

114 Fraser 2009, 19. He refers to the fact that 1941 consent decree, as amended in 1950, required the intermediaries to offer per-program (but not per-song) licenses. 620 F.2d at 933. However, these licenses were rarely used and the Court did not hold that their existence was necessary to render the blanket license procompetitive. 441 U.S. at 11-12, 20. To the extent that perprogram licenses were relevant to the $B M I$ result, the Google settlement provides the equivalent in the form of discipline-based subscriptions. See Amended Settlement $\$ 4.1(\mathrm{a})(\mathrm{v})$. The settlement just goes even further in also providing for per-book sales that parallel the per-song licenses sought by the $B M I$ plaintiff.

115 Amended Settlement $\$ 4.2(\mathrm{~b})(\mathrm{i})(1)$.

116 Initial DOJ Brief $\$ 19$. 


\section{Critic's Diagrams}

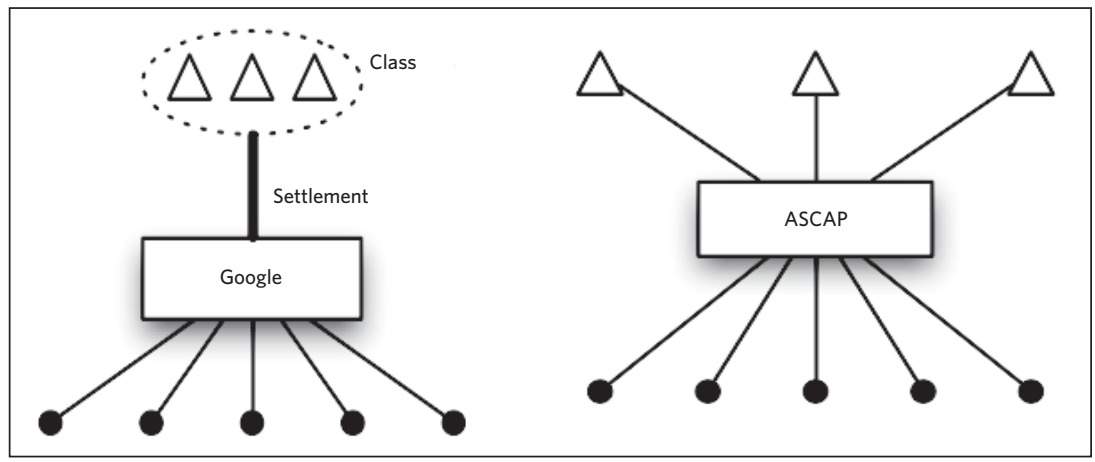

effect flowed from the fact that the plaintiff might prefer the blanket license to buying directly from individual rightsholders, as long as the plaintiff still had the latter choice. ${ }^{118}$ Adding the option of a blanket license to the option of direct licensing could not leave the plaintiff any worse off than it would have been without a blanket license, even if the blanket license might be so attractive that no one wants the direct licenses. Here the option of direct licensing provides even more of a constraint because buyers not only can buy directly from individual rightsholders, but also can buy individual books through the intermediary at a price each individual rightsholder can set.

Further, even if the reasonable-fee review were relevant to the BMI decisions, an even stronger review is supplied here by the settlement provisions requiring that book and institutional subscription prices be set to earn only competitive returns and ensure broad access. The main difference is that the standard in this settlement is far more manageable because the competitive prices for individual book sales (not available in $B M I$ ) provides some metric to use when Google prices individual books or a blanket license, and the competitive returns and broad access tests provide a more objective benchmark than the reasonable-fee test used in the BMI consent decrees.

Third, although the BMI agreement was nonexclusive in the sense that the rightsholder retained the right to license itself directly, the agreement did not allow any intermediary member to license through a rival intermediary. ${ }^{119}$ Thus, in BMI the members did have to exclusively choose one intermediary, and could not sell their songs through multiple intermediaries 
at the same time. In contrast, rightsholders here not only can license their books directly, but also remain free to license them both through Google and any Google rival at the same time. ${ }^{120}$ Thus, unlike in BMI, the settlement here does not require any rightsholder to exclusively choose one intermediary. Further, here the Registry can assemble aggregations of book rights, and it and the Fiduciary can perhaps even license default rights over commercially unavailable books. They could then license rivals who wish to offer their own institutional subscriptions, even though Google is offering the same books. Thus, the procompetitive effects created by the ability of rightsholders in $B M I$ to license directly are surpassed here by the ability of rightsholders to do not only that, but to also license Google rivals, and to have a Registry (and perhaps Fiduciary) that can license rivals in aggregate forms that can allow rivals to offer institutional subscriptions of similar sweep.

One settlement critic asserts the contrary, that the BMI agreement is less restrictive because while the BMI rightsholders negotiated with ASCAP separately, the Google settlement rightsholders effectively agreed to have one party (their class counsel) collectively negotiate with Google for them (Fraser 2009, 14). Fraser illustrates his claimed difference with the following two diagrams.

However, his diagrams fail to capture the actual set of rights and restrictions of the relevant rightsholders in numerous respects. First, his diagrams incorrectly depict the rightsholders as collectively agreeing to distribute through Google. In fact, each rightsholder individually decides whether it wants to sell through Google, and is free to change its mind at any time. ${ }^{121}$ The relationship is thus no less vertical than in BMI, and arguably less so because in $B M I$ the rightsholders agree to collectively form the ASCAP intermediary, ${ }^{122}$ whereas here the rightsholders did not form Google. Indeed, the BMI courts assumed the arrangement there constituted a horizontal agreement, and resolved the case instead on the grounds that the rightsholders remained free to sell separately. Second, his diagrams incorrectly depict the rightsholders as collectively agreeing to have class counsel or Google set their prices. In fact, the rightsholders each retain the right to

120 Amended Settlement $\$ 2.4$.

121 To the extent that Fraser's comparison rests on Google's agreement with unknown rightsholders, his diagrams are inaccurate because unknown rightsholders could not have competed without a settlement. Indeed, because the new output of their books absent the settlement is zero, any agreement to license their books can only be procompetitive.

122441 U.S. at $4-5$. 
A More Accurate Depiction

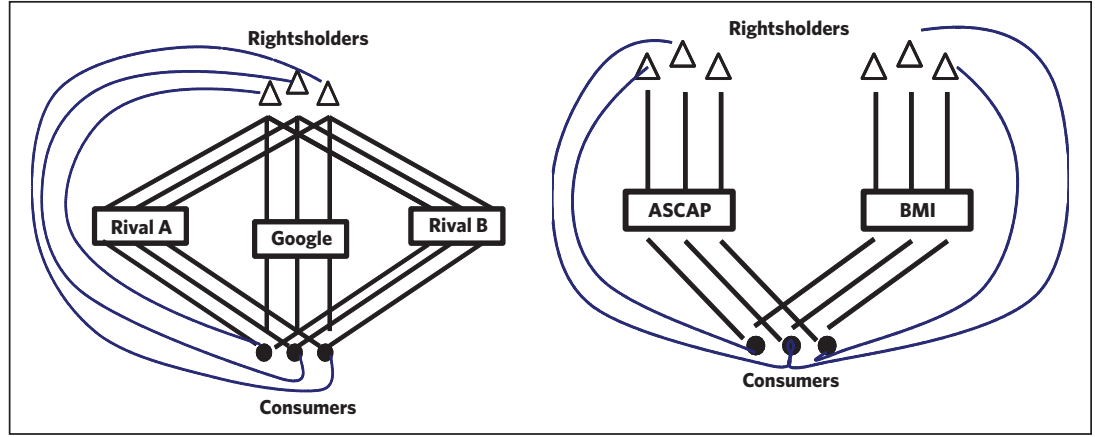

set their own prices not only directly but through Google itself, and are free to change that price at any time, whereas the $B M I$ rightsholders retained no right to individually price and sell through the intermediary. Third, his diagrams ignore the fact that, while the $B M I$ rightsholders could sell only through their intermediary, under the settlement rightsholders may sell through Google and its rival intermediaries at the same time.

A more accurate depiction of the difference would thus be the following diagrams, which include the following four important differences from the prior diagrams. (1) The parallel lines from each rightsholder to Google represent their individual vertical decisions on whether to sell through Google. (2) The fact that the rightsholders' parallel lines go through Google to buyers represents the rightsholders' ability to individually sell and set prices through Google, whereas in $B M I$ the lines from the rightsholders stop at the intermediary, rather than going through it, because they had no right to individually sell and price through their intermediary. (3) The parallel lines between rightsholders and each potential Google rival reflect the fact that rightsholders can sell through Google and its rivals at the same time, whereas in BMI the parallel lines link each rightsholder to either ASCAP or BMI but not both, representing the fact that each rightsholder could sell only through one intermediary. (4) The curved lines going from the rightsholders to the consumers depicts the fact that in both cases the rightsholders retained a right to directly license users without going through an intermediary, which is worth stressing because the BMI courts held that this factor sufficed to make the agreement there procompetitive.

Thus, Fraser entirely inverts the relationship between the Google settlement and the BMI contracts. Far from forcing more cartel-like behavior among rightsholders than in $B M I$, the settlement's terms involve no 
horizontal agreement to form or join the intermediary. Those terms also enable the rightsholders to compete by selling individual copyrighted material through the intermediary, setting prices for individual sales through the intermediary, and simultaneously selling that material through other intermediaries, all impossibilities in BMI. In short, $B M I$ not only shows that settlement critics are wrong when they assert the settlement here constitutes per se illegal horizontal price-fixing (Picker 2009c, 385; Fraser 2009, 13-15), but also establishes that the settlement here cannot be judged to fail the rule of reason that the less procompetitive $B M I$ blanket licenses passed.

\section{CONCLUSION}

Critics of the Google Books Settlement like to focus on what they call "orphan" books, meaning books I have been calling "unclaimed." But the situation regarding such books brings to mind the old Oscar Wilde quote about orphans: "To lose one parent may be regarded as a misfortune; to lose both looks like carelessness." Likewise, here, to be unable to find a book's rightholder is a misfortune, but to compound that misfortune by blocking a settlement that offers the best prospect for both finding those rightsholders and resurrecting their books if they cannot be found, would be sheer antitrust carelessness. The effects of the settlement on competition in orphan/unclaimed books is thus strongly positive, even more so when one considers that the settlement lowers barriers to rivals seeking to offer those books and requires that Google price those books at competitive rates.

The effects on other categories of books are also strongly procompetitive. The settlement clarifies which books are in the public domain and makes them digitally available for free. The settlement also expands the output of claimed in-copyright books by clarifying who holds their rights, making them all digitally searchable, allowing individual digital display and sales at competitive prices that each rightsholder can set, and creating a new subscription product that provides digital access to a nearuniversal library at free or competitive rates. The settlement does not raise rival barriers to offering any of these books, but to the contrary lowers them. The output expansion is particularly dramatic for commercially unavailable books, for which by definition there would otherwise be no new output at all. 


\section{REFERENCES}

Association of College \& Research Libraries. 2007. 2007 Statistical Summaries: Summary Data-Expenditures. Available at http://www.ala.org/ ala/mgrps/divs/acrl/publications/trends/2007/index.cfm.

Bing. 2008. Book search winding down (May 23), (italics in original). Available at http://www.bing.com/community/blogs/search/ archive/2008/05/23/book-search-winding-down.aspx.

Blair, Roger D., \& Christine A. Piette. 2006. Antitrust injury and standing in foreclosure cases. 31 Journal of Corporation Law 401-419.

Book Industry Study Group. 2006. Used-book sales: A study of the behavior, structure, size, and growth of the U.S. used-book market. New York: Book Industry Study Group.

Brynjolfsson, Erik, Yu (Jeffrey) Hu, \& Michael D. Smith. 2003. Consumer surplus in the digital economy: Estimating the value of increased product variety at online booksellers. 49 Management Science 1580-1596.

Clancy, Daniel. 2009. Increasing access to books: The Google book search settlement agreement. Available at http://www.google.com/ librariancenter/newsletter/0904.html.

Clements, Maureen. 2009. The secret of Google's book scanning machine revealed, NPR.org, April 30. Available at http://npr.org/blogs/ library/2009/04/the_granting_of_patent_7508978.html.

Council on Access to Information for Print-Disabled Canadians. 2000. "Fulfilling the promise: Report of the task force on access to information for print-disabled Canadians." October 31. Available at http:// collectionscanada.ca/accessinfo/005003-4300-e.html.

Covey, Denis T. 2005. Acquiring copyright permission to digitize and provide open access to books. Washington, D.C.: Digital Library Federation, Council on Library and Information Resources.

Darnton, Robert. 2009a. Google and the future of books. 56 New York Review of Books, February 12.

2009b. Google and the new digital future. 56 New York Review of Books, December 17.

Elhauge, Einer. 2003a. Defining better monopolization standards. 56 Stanford Law Review 253-344.

2003b. Why above-cost price cuts to drive out entrants are not predatory - and the implications for defining costs and market power. 112 Yale Law Journal 681-827. 
. 2008a. Statutory Default Rules: How to Interpret Unclear Legislation. Cambridge: Harvard University Press.

. 2008b. United States Antitrust Law and Economics. New York: Foundation Press.

- 2009a. Framing the antitrust issues in the Google books settlement. Global Competition Pol'y (October, release 2).

- 2009b. Tying, bundled discounts, and the death of the single monopoly profit theory. 123 Harvard Law Review 397-481.

- 2009c. Why the Google books settlement is procompetitive. Harvard Olin Center Discussion Paper No. 646 (September 2).

Farnsworth, E. Allan. 1990. Contracts. 2nd. ed. Boston: Little, Brown. . 2004. Farnsworth on Contracts. 3rd ed. New York: Aspen.

Federal Trade Commission \& U.S. Department of Justice. 2000. Antitrust guidelines for collaborations among competitors. Washington, D.C.

Fraser, Eric M. 2009. Antitrust and the Google books settlement: The problem of simultaneity. Stan. Tech. L. Rev. (forthcoming 2010). Available at http://ssrn.com/abstract=1417722.

Gershman, Dave. 2009. University of Michigan, Amazon announce book-printing deal. Ann Arbor News, July 21.

Gibson, James. 2008. Google's new monopoly. Washington Post, November 3, A21.

Google. 2009. The future of Google book search. Available at http://books. google.com/agreement.

Grimmelmann, James. 2009a. The Google settlement: What's right, what's wrong, what's left to do. Publishers Weekly, November 23.

- 2009b. How to fix the Google book search settlement. 12 Journal of Internet Law (April), 1-20 .

Harrington, John. 2009. Book scanning technology. Photo Business News \& Forum, May 4. Available at http://photobusinessforum.blogspot. com/2009/05/bookscanning-technology.html.

Helft, Miguel. 2008. Microsoft will shut down book search program. New York Times, May 24.

Hirtle, Peter B. 2010. Copyright term and the public domain in the United States, 1 January 2010. Cornell Copyright Information Center. Available at http://copyright.cornell.edu/resources/publicdomain.cfm.

Katz, Ariel. 2007. Making sense of nonsense: Intellectual property, antitrust, and market power. 49 Arizona Law Review 837-909. 
Oder, Norman. 2008. "Budget report 2008: Treading Carefully: Budgets nudge upward, but many libraries remain wary." Library Journal, January 15. Available at http://www.libraryjournal.com/article/CA6515839.html.

Open Book Alliance. 2009. GBS 2.0 misses the mark by a mile. November 23. Available at http://www.openbookalliance.org.

Peters, Marybeth. 2009. Statement of Marybeth Peters, register of copyrights, in Hearing on Competition and Commerce in Digital Books: The Proposed Google Book Settlement before the House Committee on the Judiciary, 111th Cong, 1st sess. Washington, D.C.

Picker, Randal C. 2009a. Antitrust and innovation: Framing baselines in the Google book settlement. Global Competition Pol'y (October, release 2).

- 2009b. Assessing competition issues in the amended Google book search settlement. Chicago Olin Working Paper No. 499 (second series) (November 16).

2009c. The Google book search settlement: A new orphan-works monopoly? 5 Journal of Competition Law \& Economics 383-409.

Quint, Barbara. 2003. "Search inside the book": Full text on Amazon. NewsBreaks, November 3. Available at http://newsbreaks.infotoday.com/ nbreader.asp?ArticleID $=16587$.

Reading Rights Coalition. 2010. How many print-disabled people are there in the United States? Available at http://www.readingrights.org/faq\#n13. Rich, Motoko. 2009. Barnes \& Noble plans an extensive e-bookstore. New York Times, July 20.

Ringer, Barbara. 1961. Study no. 31: Renewal of copyright (1960), reprinted in Library of Congress Copyright Office, Copyright Law Revision: Studies Prepared for the Subcommittee on Patents, Trademarks, and Copyrights of the Committee on the Judiciary, United States Senate. Washington, D.C.: U.S. Government Printing Office.

Samuelson, Pamela. 2009a. The dead souls of the Google book search settlement. 52 (no. 7, July) Communications of the ACM, 28-30.

- 2009b. New Google book settlement aims only to placate governments. Huffington Post, November 17.

Schinkel, Maarten Pieter. 2008. Forensic economics in competition law enforcement. 4 Journal of Competition Law \& Economics 1-30.

Stone, Brad. 2009. Sony reaches deal to share in Google's e-book library. New York Times, March 18.

U.S. Copyright Office. 2006. Report on Orphan Works. Washington, D.C.: U.S. Copyright Office. 